\title{
'A Likeness made From First Hand Witness'?: \\ The Discursive Position of a Purported Crazy Horse Photograph
}

By

Grace Campbell Russell

\begin{abstract}
A thesis
submitted to the Victoria University of Wellington

in fulfilment of the requirements for the degree of

Master of Arts

in Media Studies
\end{abstract}

Victoria University of Wellington 


\section{Abstract}

This dissertation is concerned with the ways in which photographs are discursively deployed and used in the writing of history. More specifically, it will consider how photos, and the historical, scientific, ethnographic and romantic discourses surrounding them, are used to erase or 'make safe' the traces of the radical resistances of dominated groups within colonial frameworks. The case explored here concerns the tintype photograph claimed as being of the Lakota chief and warrior Crazy Horse (c.1840-1877).

Exhibited by the Custer Battlefield Museum in Montana, the claim that this photograph is of Crazy Horse is controversial. It is generally thought that no visual likeness of Crazy Horse exists; and his refusal to be photographed can be read as a practice of opposition to his assimilation into colonial narratives and accounts of American frontier history. In claiming the photo to be of Crazy Horse, the history of his resistance is rewritten and repositioned. This changes the way he becomes knowable and understandable within the contexts of (neo)colonial discourses and narratives, in which Native Americans are often relegated to the past, and appear either as casualties of the policies of Manifest Destiny, or as a romantic other which has been symbolically integrated into American mythic culture.

This dissertation focuses on how the claim that this photograph is of Crazy Horse is made, and how the various associated cultural fields (photography, historiography, museology) are affected by, and play into, such a claim. This involves identifying the discursive processes and disciplinary mechanisms through which meaning is produced in relation to a particular cultural object. It considers the supposed photograph of Crazy Horse as an example of how history assigns significance to objects "in terms of the possibilities they generate for producing or transforming reality" (de Certeau, 1986:202), rather than as representations or reflections of reality. 


\section{Contents}

Abstract 2

Acknowledgements 4

Note on Terminology

Introduction 6

Chapter One: Project Overview, Methodology and Literature Review 8

1.1 Crazy Horse as an Historical Figure 8

1.2 Aims and Rationale 11

1.3 Historiography and Cultural Practice 12

1.4 Historiography as Discourse $\quad 14$

$\begin{array}{ll}1.5 \text { History, Fiction and the Real } & 16\end{array}$

1.6 History and Power 20

1.7 History and Silence $\quad 22$

1.8 Visual Discourse and Power $\quad 25$

1.9 Visual Discourses and Photographs of Native Americans 29

1.10 The Cultural Field of the Museum: Discourses and Contexts 32

1.11 Other Relevant Literature and Resources 34

Chapter Two: Genealogy $\quad 41$

2.1 Representations of Crazy Horse $\quad 41$

2.2 Genealogy of the Photograph 44

Chapter Three: Visual Discourse and Related Cultural Fields 64

3.1 Visual Discourse 65

3.2 Visual Discourse, Generic Modes and Photography of Native Americans

$\begin{array}{ll}\text { 3.3 The Museum as Cultural Field } & 79\end{array}$

Conclusion $\quad 88$

Bibliography $\quad 90$ 


\section{Acknowledgements}

I am extremely grateful to my supervisors, Tony Schirato and Kirsten

Thompson, for their advice and assistance during the completion of this thesis. Many thanks also to Robyn Kenealy and Marie Russell for their thoughtful feedback, and to Colin Hodson for his patience and support.

I would like to dedicate this thesis to the memory of my dear friend Tai Walker, for her encouragement in its early stages and her generosity with her knowledge and wisdom. 


\section{Note on Terminology}

In this thesis several terms are used to describe the many and varied peoples and tribes that constitute the Indigenous population of North America. For the most part, I have used the term 'Native American', which is the most widely used modern social and legal referent, though I have also used the term 'Indigenous Peoples' when the context makes it clear that I am referring to continental America specifically or to indigeneity more broadly. I have endeavoured to avoid the terms 'Indian' or 'American Indian' except when quoting other sources, as though they are sometimes still in use by some reservation and urban indigenous people as selfidentifiers (see Marshall 2007 and Newton 1994-5), others reject them as terms originating from and mainly used in Euro-American contexts, imbricated in the history of colonial oppression (Yellow Bird 1999:6).

I have used the terms 'Euro-American' and (less frequently) 'white' in reference to Americans of European descent, and occasionally to the dominant North American culture, which as a default tends to favour Anglicised perspectives, histories and ways of thinking (Deloria 1997). I have avoided using the term 'Western' to describe Euro-American views where possible, as this is complicated when the discussion at hand involves internal colonisation.

When it comes to writing of Crazy Horse and the tribe of which he is part, I have referred to the Lakota, and less frequently to the Sioux nation, which comprises the Lakota, Nakota and Dakota tribes. Where possible, when discussing individuals I have identified their clan or band as well as their tribe.

Though I acknowledge and respect Crazy Horse's Lakota name, spelled variously Tasunke Witco, Ta'shunka Witko and Thasunke Witko, (lit. HisHorse-Is-Crazy) among other phonetic approximations, I have used his anglicised name, Crazy Horse, throughout this thesis, as is the custom of many writers of both Indigenous and other ethnic identities. 


\section{Introduction}

This dissertation provides an analysis and exemplification of the ways that photography is used to establish, authorise, categorise and attest to the history of events and people as a discursive claim to truth and knowledge. More specifically, it attempts to show how power and discourse organise and inflect the writing of history. I have selected one photograph as an illustrative example of how history is discursively produced and, by extension, functions as a form of symbolic violence. This photograph, a late nineteenth century tintype, is claimed to be an image of the Oglala Lakota Sioux chief Crazy Horse.

Crazy Horse is both an important part of the narrative of Native American resistance to colonialism, and an iconic figure in North American cultural history. It is widely thought that no photographic representation of him exists, and given his political and historical significance, the provenance of any purported photographic representation of him is likely to be both contentious, and imbricated in cultural politics. Those making claims regarding the authenticity of any such representation are forced to negotiate histories which are long established, authoritative and institutionally valorised: the argument that Crazy Horse was never photographed is part of both Native and Euro-American histories, oral and written (Lippard 1992:38; Chaat Smith 1992:98; Welch 1994:116,119; Standing Bear 2006:100). These arguments are both romantically appealing (they fit in with and accentuate his messianic and mystical status) and politically motivated (Crazy Horse's purported reasons for not being photographed were tied to his anti-colonial and anti-assimilationist stance (Deloria 1969:198; Trimble 2005:n.p..).

Crazy Horse's refusals to have his photograph taken can be seen as part of a resistance to assimilation: for most of his lifetime he refused to move on to reservations or inform Indian Agents of his movements, and he avoided contact with Europeans wherever possible; only in the last six months of his life, with his followers facing starvation, did he make any moves 
towards accepting Agency assistance. His refusal to cooperate with colonial powers was a factor in his eventual murder in 1877 at Fort Robinson in northwest Nebraska. The lack of an image of Crazy Horse is in a sense emblematic of him as a figure of resistance: if photography can be understood as a culturally mediated "means of testing, confirming and constructing a total view of reality" (Berger, 1980:294), then Crazy Horse's refusal to be photographed can be read as a practice of opposition to his assimilation into colonial narratives and accounts of American frontier history, of which he is a significant part. In claiming the photo to be one of Crazy Horse, the history of his resistance is rewritten and repositioned. Nevertheless, despite the controversies inherent in claiming a photographic representation to be of Crazy Horse, several claims of this type have been made. The one this thesis considers is owned and exhibited by the Custer Battlefield Museum in Garryowen, Montana.

This thesis will, in its first chapter, provide and elaborate upon relevant background information; articulate the rationale of the project; and describe the theoretical and analytical methodologies I will use in the analysis of the image and the historiographic claims made about it. There is also a brief literature review which outlines and evaluates relevant or cognate scholarship. The second chapter will outline the narrational forms and genres through which Crazy Horse, as an historical figure, has been discussed, and then undertake a Foucauldian genealogical investigation of the texts and documents which are cited as evidence of the Custer Battlefield Museum's claim that their photograph is of Crazy Horse. I hope to show how such a claim is constituted, authorised and maintained, while disguising its involvement in what Foucault refers to as the power/knowledge nexus. The third and final chapter considers the cultural fields in which this photograph appears, and how the discourses of these fields affect how viewers are disposed to read the image: the (sub)cultural fields of particular relevance are photography and visual culture; late nineteenth and early twentieth century photography of Native Americans; and the museum as cultural field. 


\section{Chapter One: Project Overview, Methodology and Literature Review}

\section{$\underline{\text { Introduction }}$}

Before analysing the photograph, the scholarly claims made about it, and its discursive trajectory, meanings and functions, it is necessary to provide some contextual material. This chapter will provide that context, most particularly with regard to who Crazy Horse was, his significance as an historical figure, and some of the events of his life which have bearing on this study. It will then discuss the aims and rationales of the study; describe and evaluate the theoretical and methodological tools and practices which will be used to conduct the analysis, and provide a review of relevant literature.

\subsection{Crazy Horse as an Historical Figure}

Crazy Horse stands as "arguably the best-known Lakota leader in the latter half of the nineteenth century" (Marshall 2004:xii), and as such some discussion of who he was is pertinent to an understanding of why the claim of photographic representation of him is so strongly debated and contested. This section's recounting of some of the events of his life is intended to orient any reader unfamiliar with Crazy Horse as to who he was and why he is so well known and well regarded. However it is by no means comprehensive or exhaustive. The central concern of this thesis is not to tell the story of Crazy Horse, but to analyse the ways historiography has been shaped regarding representations of him; the biographical summary here merely foregrounds some of the events referenced, and situates discussion of the 'legendary' Crazy Horse in relation to a specific time and place.

Crazy Horse was born c. 1840, in the area now known as South Dakota. His father was an Oglala Lakota Sioux, and his mother was from the Miniconjou band. As a young man, he earned reputation and fame as a skilled warrior in battles with Crow, Shoshoni, Pawnee and U.S. Army enemies, eventually earning the title of Shirt Wearer (war leader) in 1868 (Bray 2006:416). At this time, the United States government, eager to open passage to the 
West Coast and to exploit the gold-rich central plateau in order to haul the nation out of post-Civil War debt (Bray 2006:180), engaged the Sioux, along with their Cheyenne and Arapaho allies, in numerous battles. These are referred to collectively as the Sioux Wars, and they lasted from 1854 to 1890; the wars of particular note in this period including Red Cloud's War (1866-68) and The Great Sioux War (1876). Crazy Horse, along with other Lakota chiefs of the time such as Red Cloud and Sitting Bull of the Oglalas, the Brule chief Spotted Tail, and Gall of the Hunkpapas, became well known to Euro-Americans owing to their roles in these conflicts.

Crazy Horse's war successes at the Battle of the Hundred in the Hand (1866, also known to Euro-Americans as the Fetterman Massacre), the Wagon Box Fight (1867), the Battle of the Rosebud (1876) and the Battle of the Little Bighorn (1876, also known as Custer's Last Stand and known by the Lakota as the Battle of the Greasy Grass), confirmed his status as a leader and strategist, though this career was not without controversy. In 1867, Crazy Horse and Black Buffalo Woman, the wife of No Water, ran away together (Lakota custom allowed for women to divorce). No Water pursued them and shot Crazy Horse in the face with a small calibre pistol, the wound leaving permanent scarring. As a result of the scandal Crazy Horse was stripped of the title of shirt wearer. He married Black Shawl in 1871, and Nellie Laribee in 1877. He had only one child, the daughter of Black Shawl, named They Are Afraid of Her, who died at the age of three.

Crazy Horse's death has been written about frequently and extensively, particularly by Euro-Americans, to the extent that the events leading up to and surrounding his death are what is best known about him in EuroAmerican history. After the Lakota victory at the Battle of the Little Bighorn, the pressure to move the Lakota onto reservations increased: according to Buecker, "by the late spring of 1877, only the bands under Sitting Bull, Lame Deer and Crazy Horse remained free" (1994:1). Having suffered a hard winter, and with considerable illnesses amongst his followers, Crazy Horse surrendered with his band at the Red Cloud Agency near Fort Robinson in Nebraska on May $5^{\text {th }} 1877$. 
Initially Crazy Horse enjoyed great popularity at Red Cloud and the nearby Spotted Tail Agency among the Lakota, and wary admiration from the army officers (Bourke 1971:415), though in the ensuing months this popularity led to jealousy from the other Lakota leaders. Crazy Horse's desire to leave the Agency made the army nervous: a series of rumours, misunderstandings and betrayals led to Crazy Horse leaving the Red Cloud Agency with about a hundred followers. The army pursued and brought them back: the Indian Agent stationed there, Lieutenant William P. Clark, intended to imprison Crazy Horse. On being ushered into the guardhouse, Crazy Horse resisted, drawing a knife, and was bayoneted in the side by an officer. He died later that night, and his body was then moved to Spotted Tail Agency, and then buried in secret at an undisclosed location by his family.

The emphasis on the respect Crazy Horse inspired in his own people and the fear the U.S. Army had of him is evident in most biographical accounts. His refusals to cooperate or defer to Euro-American authorities and demands, as well as his resistance to acquiescing to reservation life have, over the course of the twentieth century, achieved an almost legendary status. It was in this environment of admiration and eulogising, from both Native and Euro-American commentators, that the claims that Crazy Horse was photographed appeared.

The Custer Battlefield Museum's tintype, while perhaps the most wellknown and hotly debated image claimed as being of Crazy Horse, is not the only image subject to such claims. Other prominent examples include an image taken by S.J. Morrow, which is in the archives of the University of South Dakota, and which was published in activist Ward Churchill's book Agents of Repression (1988:110) as an authentic photograph of Crazy Horse. The University of South Dakota later refuted that claim, identifying the Morrow photograph as being of the Brule Sioux Crazy in the Lodge ('Alleged Photo of Ta'Shunke Witco' n.d.). Other photographs have also, at various points, been claimed as being of Crazy Horse. The number of such images is indicative of the strong desire of those with an interest in his 
history to know precisely what he looked like. Nevertheless, I have chosen to focus on the tintype exhibited by the Custer Battlefield Museum, as the claims regarding this image are the longest standing, and most widely subject to scholarly attention, analysis and debate.

\subsection{Aims and Rationale}

In making claims regarding the provenance of a photographic representation of Crazy Horse, the Custer Battlefield Museum is not simply stating a fact which can then be debated as truthful or false, but is making a discursive statement which shapes how a particular history is understood and deployed as meaningful. This study aims to investigate what some of these meanings are, how they are constituted, and how they are disseminated as forms of knowledge about Crazy Horse and his life, and more generally about indigenous Americans.

While the controversies around depictions of Crazy Horse have been considered in academic contexts, these inquiries have tended to focus on the evidence for or against claims that he was photographed (Heriard 2004; Hagengruber 2003; Rieckmann 2003), or have considered the ethics and legality of posthumous attempts to represent him, as with the also controversial Crazy Horse Monument (discussed in Fisher 2011; Blair and Michel 2004), and the 1992 Crazy Horse Malt Liquor lawsuit (Newton 19945; Herrera 1994). Instead of evaluating the photograph and this claim in terms of whether the evidence is accurate or persuasive, this dissertation considers this claim as a form of cultural work. In doing so, I hope to demonstrate how such claims involve an operation of power which continues and extends the violences of colonialism.

In this dissertation I am writing as a non-indigenous person and a nonAmerican; as such I do not claim to represent or speak for indigenous experience or views. Rather, in considering the claims regarding indigenous subjects made by others, I intend to show how these claims are part of, and are authorised by and through, the wider power/knowledge nexus. 


\section{$\underline{1.3 \text { Historiography and Cultural Practice }}$}

The case of the purported Crazy Horse photograph and the claims regarding its provenance by the Custer Battlefield Museum constitute a rewriting of history. As such, a consideration of what historiography is and how it operates is necessary here. Accordingly, the work of Michel de Certeau is central to my analysis. de Certeau analyses the relational operations that constitute culture, and demonstrates how they affect dominated groups - by which he means the consumers, rather than the producers, of popular space and culture. In looking at these relational operations with regard to the photo claimed to be of Crazy Horse, it is evident that prior knowledges (of culture, of history, of Native Americans and of colonialism) influence how the text is read and deployed as a form of knowledge. de Certeau's work emphasises the notion of cultural practice, but in ways that both incorporate and extend the Foucauldian conceptualisation of power/knowledge.

The issues of how the photograph, and the claims and discourses that characterise it, operate as a rewriting of history can be addressed via de Certeau's articulation of what historiography is and how it functions; his books Heterologies (1986) and The Writing of History (1988) are particularly relevant to such a discussion. In the chapter 'History: Science and Fiction' in Heterologies, de Certeau argues that history is framed as a relating of facts: we see realism in history, not reality. According to Barthes, "the invocation of 'it happened' is the primary justification of the discourse" (cited in de Certeau 1988:42). When history tells us 'it happened', it is providing a narrative about the past, and about its own productive activity; that is, it facilitates access to the events, texts and structures which produce and make 'the thinkable' something that we recognise (1988:44).

All historiographical research and writing is authorised by and takes place within its own cultural field, which in itself is part of and derived from a wider social field (Bourdieu 1993); consequently it is always "ruled by constraints, bound to privileges, and rooted in a particular situation" (de 
Certeau 1988:58). Questions regarding the supposed objectivity of historiographical research are necessarily spoken by and through the field, and by extension through the disciplinary habitus of the researcher; this leads, de Certeau writes, to "an era of suspicion" (1988:58) with regard to history, where the status of any claim needs to be interrogated. The process of this interrogation, however, is tied in with a discursive philosophy and regime of self-perpetuation and justification, where practitioners are disposed to foreclose their own ideological presumptions while conducting their analysis; the upshot of which is that they then place themselves in "a privileged relation to ideas" (1988:59). de Certeau suggests that Foucault's The Archaeology of Knowledge (1972) offers a way around and through this problem, in that it introduces "at once both social conflicts and the techniques of a discipline into the examination of an epistemological structure, notably that of history" (1988:60). My second chapter will interrogate the photograph as an historical product through this framework (which will be elaborated further in this chapter).

The increasing specialisation of disciplines means that institutions determine and allow for schools of thought to "have a social position" (de Certeau 1988:61). Failure to acknowledge how the workings of a discipline explain or play out in practice leads to an abstraction, where the discipline "denies the very matter with respect to which it is elaborated" (de Certeau 1988:62). In this case, the Custer Battlefield Museum cannot elaborate the workings of its claim, as to do so would reveal the symbolic violence it perpetrates: in other words, it would invalidate its social and cultural position, jeopardising its authority. For de Certeau, historiography does not involve merely asserting facts; in making any historiographic statement, one is also making a discursive statement, and effectively 'remaking the world'. The claims regarding the photograph purported to be of Crazy Horse are examples of discursive processes, and as such cannot be evaluated simply as matters of truth or falsity. Rather, the concern is how these claims are constituted as knowledge. In order to do this, particular forms and sources of knowledge are privileged over others, in order to 
establish that the claim that Crazy Horse was photographed is an incontrovertible and canonical truth.

\section{$\underline{1.4 \text { Historiography as Discourse }}$}

For Foucault, the discursive status of historiography is predicated on the relationship between history and power. Power relations are evident in the structure of history both as a discipline and as a product: discontinuities are always evident in the operations of historiography, as the institution (university, library, museum - wherever the work is validated) "will shape how the history will be written, and how the different historical events will be fitted together to form a coherent vision" (Schirato et al. 2012:4). This means that dissenting voices or alternate views are glossed over, and elements that do not fit into the (written) continuity - for example oral histories - get left out, although the gap left by their absence has the potential to disrupt this continuity. Furthermore, in the teleological process of refining, improving and correcting what we already know, discontinuities become evident in the rejection of past knowledge. Foucault quotes Althusser, writing that historiography establishes a truth by "detaching it from the ideology of its past and by revealing this past as ideological" (Foucault 1972:5).

Genealogy and archaeology are the two methods Foucault employs to interrogate the imbrication of history and discursive regimes. Both methods propose that universality cannot be debunked or demonstrated by "using history as a critical method" (cited in Schirato et al, 2012:6). For Foucault, since universality does not exist, theoretical investigations should consider what kinds of historical work could be done without recourse to it. For Foucault this means identifying and articulating the ways in which dominant power structures operate, interact with each other, and impose and naturalise their authority. Power in the Foucaldian sense is not something that is held or bestowed, nor does it exist as an entity in itself: instead it is relational, and it ebbs and flows in a manner that is both "arbitrary (in the sense that any configuration of ideas, technologies and contexts is an accident, subject to the dislocations of time and space) and 
motivated (what is naturalised as powerful always seeks to arrest that situation for its own benefit" (Schirato et al, 2012:8).

By way of example, we can say that the processes of canonisation, and the organisation of history into genres, disciplines, movements and authorships, are "always implicated in and derived from networks and forces of power" (Schirato et al, 2012:11). Accordingly, genealogy asks on what grounds a system of classification can be founded: what is the basis for it to be believable or even comprehensible, how is it mediated, and how does it change? Furthermore, if we order and classify things, what is included or excluded, and what constitutes a category's other or opposite? Once these categories are naturalised, they appear as reality, rather than "an historically based system of thought" (Schirato et al, 2012:15). Bourdieu refers to the process where an historically and socially constituted idea is actualised, validated and legitimised - by economic, academic, cultural and other forms of capital - as a form of "social magic" (Bourdieu 1991: 120). Through the progression of this operation, what we believe now can gradually replace what we used to believe, giving the impression of a seamless history. Genealogy, as a methodological tool, deals with "the violence and exercising of power that is history" (Schirato et al. 2012:39), and by extension the way discourses dispose and discipline bodies as subjects. The body is important here: it is inscribed by history, and as such one of the tasks of genealogy "is to expose a body totally imprinted by history and the process of history's destruction of the body" (Foucault 1977:148). This involves looking at the ways in which the body is subjected, how that subjection works, and the forms and trajectories that it takes.

The discussion and analysis, in the following chapter, of the photograph purported to be of Crazy Horse will utilise genealogical approaches in order to interrogate the relation between historiography and power, and to discern what the effects of it are as a discursive practice. This involves giving an account of the texts the photograph has appeared in, retracing the other texts they call on as evidence of their claims, and examining the 
language used in making the claim that the photograph is of Crazy Horse. Through this genealogy, it becomes evident how these discursive statements privilege certain power relations and forms of knowledge, transforming them into 'truth'. These operations of power discipline and dispose both social and individual bodies to particular subject positions.

Archaeological research, in the Foucaldian sense, identifies and analyses the changes to discursive formations that stem from particular institutional and disciplinary concerns. Its work is to interrogate discontinuities that are presented as progress, methodological or technical developments, or as breakthroughs in the accumulation of knowledge. These discontinuities allow us to think of history as linear and continuous, and as moving from something which is now understood as qualified or limited to a more complete, sophisticated or methodologically sound epistemology. These are what Foucault would call 'epistemic changes' (Foucault 1972). The second chapter of this thesis utilises archaeological techniques to highlight how the claim that Crazy Horse was photographed has been produced over time through the accumulation of documents and statements, and through different discursive modes of address, subject to the cultural politics of the times and places in which they were produced.

\subsection{History, Fiction and the Real}

The ways in which historiography produces and inflects what is constituted as knowledge, and by contrast what is produced as fictional, are considered in this section. As the purported Crazy Horse photograph is used to articulate various supposed truths about history, the way that history, as a discipline, is able to authorise its products as truthful and as separate from what it designates as fiction informs the analysis of the photograph and the claims made about it. These truths are made meaningful through being discursively produced, articulated and deployed in various cultural fields.

The way in which historiography validates its status is predominantly through positioning itself as a record of reality. The various cultural fields 
that constitute the human sciences are characterised by, and necessarily perform a commitment to, both technical and ethical discourses. However, they are less concerned with ethical issues and more with prescribing truth. de Certeau refers to this praxis as "the institution of the real" (1986:200), whereby reality is constructed through representation. He analyses this hypothesis in relation to the concept of 'fiction': history distinguishes itself from everyday historical discourses such as myth, oral tradition, storytelling, belief and so on, through the cultural capital accredited it by the Western academy (it is something that scholars do, facilitated by specialist knowledge and skill). Fiction does not attempt to speak for or represent what is real, even though it informs and influences our understanding of reality. Historiography does aim to represent the real, in a more or less totalising manner.

The credibility and status of historiographic writing and research are tied in with what they render possible about a subject: they are important in terms of "the possibilities they generate for producing or transforming reality" (de Certeau 1986:202). The historiography produced around the photograph, in disavowing what it frames as fiction in order to legitimise itself, nevertheless continues to be bound up in the techniques of fiction. As de Certeau points out, fiction relies on nuance, interpretation, metaphor, and on the possibility of different readings. This is something history, as a discipline, is always forced to consider, confront and discursively negotiate in its process of constructing the 'realities' of the past. However, in doing this, historiography represents only the past - it does not represent the present which produces and organises that past. It hides the "social and technical apparatus of the professional institution" (de Certeau 1986:203) which authorises the 'real': as de Certeau writes, "representation thus disguises the praxis that organizes it" (1986:203). The claim that Crazy Horse was photographed is predicated on institutional and disciplinary authority to authorise the 'real', and the power to entertain or dismiss opposing arguments as expedient. Those claiming the photograph is of Crazy Horse are able to selectively omit or incorporate elements of 
different histories, and discard the parts omitted as pejoratively fictional. One notable omission is any reflection on (institutional, cultural, political) practices which authorise or aid in producing this history.

These omissions illustrate how work by a collective academic community is subject to political, economic, temporal and technological constraints, as well as the histories, forms of habitus, logics and imperatives of the institutions that help constitute it. The research produced by the institution hides these influences, since authorised texts only refer to the institutional practices governing them in a tangential manner. So while historiography organises the past into a meaningful unity, it does so by producing representations which conceal the conditions and what we might call the 'cultural politics' of that production; in effect the significance of the representation of the real is prioritised over the significance of the organisational praxis.

Historical representations can be seen as the myths or stories which explain the discourses governing social practice. This is important in a scientific, rational, technologised discursive regime which does not subscribe to the notion of storytelling and myth as legitimate forms of knowledge. Moreover, the relations between and within disciplines mean that status, authoritativeness and credibility are always the subject of competition and dispute within and across those disciplines. As Deloria explains:

Any group that wishes to be regarded as the authority in a human society must not simply banish or discredit the views of their rivals, they must become the sole source of truth for that society and defend their status and the power to interpret against all comers (1997:26).

Science and history both do this, de Certeau argues, by first defining the concept of fiction and then separating themselves from it. They privilege the need to be associated with the production of truths, rather than with the processes and techniques of objectivity; as Deloria writes, "the most 
fatal counter-attack against entrenched authority will not be directed against their facts but against their status" (1997:26). By this he refers to both the institutional, disciplinary and social status of those in authority, and the status of the supposed truths those authorities produce.

There are various fields where an episteme organises, produces and deploys something as having the status of truth. Foucault is less concerned with proving or disproving truth claims, instead focusing on "why we are so concerned with truth, and then with how we deploy the concept of truth in order to play the game of power" (Schirato et al 2012:32). Forms of truth can only be held as self-evident when we analyse and expose the conditions and flows of power that allow them to be constituted as true, and the forms of power they help maintain. At the level of discourse, this type of analysis is concerned with identifying the rules that govern discursive acts and statements. Foucaldian discourse analysis is not just about the selection and use of signs and sign systems: it is more interested in how signs come to have meaning and how that meaning is put to use, as well as how it changes. It is not speech and signs (that is, units of meaning) that organise discourse; rather, discourse organises the units of meaning. In other words, discourse analysis involves looking at the rules that constitute statements and where those statements are then put to work, rather than analysing what the content of the statements is or the different ways they can be interpreted. For Foucault a discursive statement is both an activity derived from and formed by the rules of a discursive regime, and something that, through its iterations "constitutes one of the organising principles for activity, and helps establish the conditions of truth, within a cultural field" (Schirato et al 2012:36). This investigation of the relations of power which produce what is accepted as true is relevant to my second chapter's analysis of how historical relevance is constituted, and to the third chapter's discussion of how these truths are influenced and inflected by the discourses of the cultural fields in which the photograph appears. 


\section{$\underline{1.6 \text { History and Power }}$}

With regards to the purported Crazy Horse photo, we are shown a scenario where Crazy Horse supposedly allowed a white photographer to take his picture, and an image as evidence of this. In other words, the status of technology and technological discourse support the historiographic claim that Crazy Horse was photographed. Technology maintains a symbolic power within the field of history, as its presence both legitimises the field and, at the same time, acknowledges the power of technology as the prime force of rationality in modern Western society. Citing technological operations, then, is one of the way that historiography maintains its privileged relationship to the real: the real is created and legitimised through operations of power, and by paying tribute to the symbolic power of technology, historiography "produces the belief that it is not fiction" (de Certeau 1986:213). An example of this are the references to photographic and forensic technology, which the Custer Battlefield Museum cites as proof ('Portrait of Chief Crazy Horse', 2009: n.p., Rieckmann 2003:n.p..): these supposedly reveal the facial scar Crazy Horse is known to have had, and are deployed in order to reinforce the museum's authoritative position in relation to supposedly specialised or complex knowledge. Such citations capitalise on the discursive framing of science and technology as inherently rational and objective.

de Certeau criticises the claims of objectivity, neutrality and disinterestedness that characterise scientific institutions. He makes the point that the logics and practices of a cultural field are constituted by and through relations of power, which produce the categories and mechanisms that are used to understand and negotiate the world. Historiography is always motivated and disposed by the time and place in which it operates and to which it has to justify itself; consequently it can never fully articulate its own relations to power. The interrogation and analysis of the past cannot, in any pragmatic sense, involve an interrogation and analysis of the historian's own practice which produces, represents and speaks for that past. This is evident in the Custer Battlefield Museum's foreclosure of any 
interrogation of their own praxis: any such reflection would reveal the cultural politics of their claim, which would contravene the claims to neutrality which historiography still, at least in popular historical narrativisations, tends to strive for.

The purported Crazy Horse photograph, and the historiographic work surrounding it, focuses on the historian's present - the ways in which an item (the photograph) is rendered relevant, significant and intelligible within an historical context and inventory. This involves negotiating the claims that he was never photographed, and evaluating and (re)narrativising what is already known about his life. It does, however, also incorporate the more descriptive, literary aspects of historiography's other position regarding knowledge about the past, a position which "would like to restore the forgotten and to meet again men of the past amidst the traces they have left" (de Certeau 1988:35-6). This means that two discursive modes are often in play in the texts which claim the photograph is of Crazy Horse: firstly, a supposedly objective, technological, evidencedriven discourse; and secondly, an imaginative, reverential mode, where viewers are asked to contemplate and admire Crazy Horse as a romantic hero.

de Certeau suggests that we define the past as those elements that do not "belong to the power of producing a present" (1986:216). In this way, the production of the present sets itself up in opposition to the past which is its object of study. Historiographic practice, in elucidating both past events and its own relation to power, is unable to directly confront the instances where the two meet; if past events, particularly violent ones, organise current praxis, then history cannot address them, as to do so would run the risk of invalidating that praxis. The address of past or current violences is only possible when it does not interrupt the systems on which historiography - or social life more generally - rely. This is why the figure of 'the other' is historiography's object: it can discuss and analyse the violences of past events and power differentials, but not those which are constitutive of or facilitate historiography itself. 
Historiography therefore reinforces the difference between itself and 'the other', its object. For de Certeau, "the function of history expresses the position of one generation in relation to preceding ones by stating 'I can't be that'" (1988:46). The historiography regarding the purported Crazy Horse photograph therefore regards the people, events and relationships of the past as very separate from the present, with little relevance or bearing on it.

This perspective is institutionally valorised and culturally specific. As Deloria writes, many indigenous methodologies do not subscribe to the disinterestedness and supposed impartiality that characterise Western expression of knowledge (Deloria 1997:40), and, in Lakota tribal practice, the people of the past maintain a strong presence in the relationships and activities of contemporary life (Newton 1994-5:1047). The separation of past and present can be seen in the exhibition and promotion of the purported Crazy Horse photograph, and it allows for the omission and foreclosure of the cultural politics spoken by the claim.

\section{$\underline{1.7 \text { History and Silence }}$}

The claim that the Custer Battlefield Museum's photograph is of Crazy Horse involves a cultural practice whereby truth claims are naturalised through the operations of discourse. Since discursive processes always involve an operation of power, this thesis is also concerned with what some of the effects of this discourse are: what relations of power are exercised here, and what might that mean for the subjects concerned? For Foucault and de Certeau, the way that a discourse or position is established as truth invariably involves forms of symbolic violence. Some of these are invisible or unable to be articulated (the enforced silencing of alternative histories is always a violence in itself), while others manifest as arguments, conflicts, revolutions and wars. Foucault argues that these forms of violence never play themselves out, since acts and regimes of domination are always inverted or replaced by other dominations. Power flows 
through and across agents rather being held by them, but is always based on a sedimentation of violence.

According to de Certeau, prejudices and conflicts which shaped past historiographies can, from the present, be analysed much more impartially, as the arguments are no longer of such immediate concern. When an area of history becomes "a poorly defined and poorly understood region" (de Certeau 1988:33), then modern historiography is able to treat that area of history as "a new exoticism" (1988:33). If it is not a history which directly concerns one's group, family, culture or beliefs, then one can view the modes of comprehension of the past as prejudices (1988:34). What de Certeau fails to emphasise here is that in treating the past as a 'new exoticism', modern historiography still draws on current social praxis to render such exotic viewpoints comprehensible in relation to current ones. Even if we regard the actions of past writers about Crazy Horse, his friends, enemies, and even Crazy Horse himself as being informed and inflected by agendas which no longer have relevance, we are drawing on current (and culturally mediated) ideas and assumptions about which viewpoints and ideologies are of concern and which are not. In locating certain prejudices in the past, there is a risk that their present manifestations are being made invisible, and that one particular "position of the real" (1988:35) will be treated as of especial relevance.

Both the photograph exhibited as being of Crazy Horse, and the museum context in which it appears, are not only associated with Crazy Horse as an historical figure: they are also emblematic of a set of historical events and conflicts involving both a specific a group (the Lakota) and Native Americans more generally. Within the museum context, knowledge about the photograph is framed as being for the benefit of a generalised (commercial) audience and of cultural significance to all Americans, rather than only to Crazy Horse's tribe and descendants. In his chapter 'The Beauty of the Dead' (de Certeau 1986) de Certeau writes about the ways in which high and academic cultures make use of 'the popular', specifically knowledge or artefacts produced by or of significance to groups 'othered' 
by powerful institutions. The popular cultural products of dominated groups therefore became part of an archive for the inspiration of legitimate (that is, high culture) artists and institutions. The valorisation of positive qualities of marginalised groups is also strongly tied to nationalism, most particularly in terms of minorities' separation from urban environments and their corrupting (and foreign) influences: in terms of the purported Crazy Horse photograph, this nationalism is bound up in the romance associated with the American West and frontier history. The people become an exotic other, but one that is the safe and interesting object of curiosity and study. The late twentieth century move to appropriate and claim Native American art, spirituality and even lineage is an example of this tendency (Deloria 1999:235, 251, 257).

de Certeau writes of how this idealised view of dominated and marginalised groups works to efface the violence that, amongst other things, produced them as marginalised in the first place:

The elimination of violence from the study of localisms and popular culture is explained by a political violence. What allowed these lost paradises to be handed over to the scholars was in every instance the victory of a certain power. We cannot reproach the literature for grafting itself upon a prior violence (for that is always the case); but we can reproach it for not admitting it (de Certeau 1986:134). As de Certeau argues, treating minority cultures as objects denies the status of culture as a practice - which has the effect of silencing it. He suggests that historiography can only speak to, see, and understand what it already knows; in other words it can't hear, pay attention to or accept those voices that are not legitimised and already explicated. For de Certeau, this means that "scientific studies - and undoubtedly the works they highlight - include vast and strange expanses of silence" (1986:131). Historical practice is situated within and inflected by wider socio-cultural changes, and the emphasis on alternative views of history, however minute, reflects changes to the discursive regime from which any 
historiographic position exists and speaks. This "brings neither better nor more objective conceptions, but does indicate a different situation" (de Certeau 1986:67) in which new information or interpretations can be accepted, particularly when there is little at stake in the historical conflicts which have occurred. In treating the circumstances of Crazy Horse's life as of relevance only as a historical curiosity, the introduction of new information, in the form of the claim that he was photographed, can be made without consideration of the forms of symbolic violence and subjection such a claim effects.

\section{$\underline{1.8 \text { Visual Discourse and Power }}$}

Discursive statements are often made in or with regard to texts or documents. Documents have an undoubted value for historians: they can be used to prove or disprove truth claims, to measure the claims or rights of groups or individuals, or to "reconstitute the past from which they emanate" (Foucault, 1972:6). They also shore up the discourse of history as cultural memory, and help transform it into a totality. In this dissertation the most relevant documents include the articles, webpages and books through which the museum makes and finds evidence for their claim, but also, and particularly, the photograph itself. This section considers the ways in which the visual (particularly photography) operates discursively; this will be taken up and considered in relation to the purported Crazy Horse photograph in further detail in chapter three.

Jonathan Crary's Techniques of the Observer (1990) provides a useful theoretical supplement to de Certeau and Foucault's conceptions of historiography as discursive praxis, specifically with regard to his work on the cultural politics and history of visuality - elements which any consideration and analysis of the supposed Crazy Horse photo must take into account. Crary's book is a genealogical study of visuality and art history: it investigates the historical disjunctures and transformations with regard to the ways we see, with particular reference to the Foucaldian question of relations between subjectivity, disciplinarity and biopower. He focuses particularly on the early nineteenth century and how, in this 
period, the relations between "the body and the operation of social power" (Crary 1990:3) were changed.

The ways in which concepts such as 'realism' were understood supposedly underwent a radical transformation post-Renaissance, a rupture which is usually explained by technological advancements and developments (for example the camera obscura, photography and the moving image). Crary identifies this rupture, however, with the "reorganization of knowledge and social practices that modified in myriad ways the productive, cognitive, and desiring capacities of the human subject" (1990:3). This is not to say that changes are not brought about by new material and technological inventions; rather, the ways in which such changes have been interpreted fail to appreciate the significance of the new relationship that is posited between subjectivity, seeing and sight.

The way in which a subject observes is not the product of one overarching discourse, structure or economic situation; following Foucault, Crary is interested in the numerous different social and discursive influences which converge to determine historically specific ways of seeing (1990:6). Different contexts will also determine the way in which these discourses and structures play out, and circumscribe the possibilities of visual perception at given points in time. Thus, when discussing the various technological inventions of the early nineteenth century, Crary does not analyse how they changed the way we understand representational models or aesthetic shifts, but instead how they operate to facilitate biopower, and extend systems of bodily control (1990:8). For Crary, different technologies operate in similar, though not transposable, ways: though photographs and the movie camera may both, for instance, depict a form of realism or encourage an understanding of subjective vision, those forms and that understanding will be specific to historical and cultural contexts.

Crary notes that in undertaking a genealogy of observation in the nineteenth century, his study does not go into the "marginal and local 
forms by which dominant practices of vision were resisted, deflected, or imperfectly constituted" (1990:7). While he fully acknowledges how valuable such histories are, he points out that they only become "legible against the more hegemonic set of discourses and practices in which vision took shape" (1990:7). While this may be accurate, it is only so due to a legibility which is decided on by powerful institutions (academe, government, the media and so on), and which authorise the dominant practice of vision. As Crary writes, the decisions over what constitutes the dominant and where we locate historical ruptures are political decisions which:

determine the construction of the present. Whether one excludes or foregrounds certain events and processes at the expense of others affects the intelligibility of the contemporary functioning of power in which we are ourselves enmeshed. Such choices affect whether the shape of the present seems "natural" or whether its historically fabricated and densely sedimented makeup is made evident (1990:7).

In the case of the photograph claimed as being of Crazy Horse, what constitutes dominant vision and how viewers are disposed to read, interpret and identify with the image strongly affects how the photograph functions discursively.

Crary points to the conditions of modern capitalism as being particularly influential in shaping our understanding of subjectivity, both as a concept and as something embodied at an everyday level. He argues that capitalism uproots and makes mobile that which is grounded, clears away or obliterates that which impedes circulation, and makes exchangeable what is singular. This applies as much to bodies, signs, images, languages, kinship relations, religious practices and nationalities as it does to commodities, wealth and labor power (1990:10). 
One way in which it does this is by making abstract notions and capitalised ideas (such as emotional states, equality, freedom, resistance and so on) visible and quantifiable in material form. If these notions and ideas are made "measurable in terms of objects and signs" (1990:11), then they are provable. As Adorno emphasises, this makes us observers or witnesses to bourgeois rationality - to "perceiving reality as a reality of objects and hence basically of commodities" (cited in Crary, 1990:11). It is helpful, then, to think of photography not simply as a new form of visual representation, but as an innovative commodity within a particular economic system. Crary draws an analogy between photography and money in terms of their social power: both supposedly are democratising forms which treat all subjects the same, and both are "magical forms that establish a new set of abstract relations between individuals and things and impose those relations as the real" (1990:13). Photography, therefore, is not prized because it represents reality, but rather because of its usefulness as a means of mobilising visuality and making it exchangeable.

What does this understanding of photography and visuality mean for the subject? Returning to Foucault, we can see that historically "the management of subjects depended above all on the accumulation of knowledge about them" (Crary, 1990:15). This knowledge, gathered from various fields is then redeployed as the basis of practices of disciplinarity which make "the subject ... visible" (Crary, 1990:16, emphasis in original). This 'will to visibility' acts as a form of discipline in that it says, in effect, that you do not exist until you can be seen. This is incredibly important, if we consider how Crazy Horse's refusal to be photographed - a literal refusal to be seen and regarded as a knowable object - can be understood as a form of indigenous resistance: in a frame where the will to visibility operates, this expression of power meets strong opposition.

The understanding of the will to visibility is where Crary diverges from Foucault's explanation of how the visual is used as a form of discipline. While Foucault tends to emphasise surveillance and dismiss the Debordian notion of spectacle, through which subjects are disciplined and disposed by 
images, Crary posits that the two regimes (surveillance and spectacle) are not mutually exclusive, and that 'spectacular' technologies such as photographic exhibitions have involved "no less than the panopticon ... arrangements of bodies in space, regulations of activity, and the deployment of individual bodies, which codified and normalized the observer within rigidly defined systems of visual consumption" (1990:18). Knowledge of how we are watched also influences how we watch. This theoretical point is relevant to the case of the Crazy Horse photo, in that the way we read the image, and the extent to which we accept the historiography it is purported to represent are contingent on the discourses and expected modes of behaviour viewers are conditioned to inhabit when they observe and react to photographs. One important aspect of the ways we are disposed to read this image is the relationship between Native American history and photographic documentation.

\subsection{Visual Discourses and Photographs of Native Americans}

As Crary points out, photographs are derived from, and tend to reproduce and naturalise, discursive regimes and perspectives. The supposed ability of photography to provide us with a truthful reflection of reality ignores the socio-cultural dispositions that are built into the intervention and use of the camera lens: photographing something does not take away the interpretive work (selection, omission, focus, framing) that helps produce the photographic image as a presumed reflection of reality. Authorised discourses about and accounts of Native Americans have, therefore, dictated the dominant readings of photographs taken of them ${ }^{1}$. These readings, though not singular, monolithic or static, have been overwhelmingly produced as nostalgic and pitying with regards their subjects, (at least since the late nineteenth century): they have largely

\footnotetext{
Until the latter half of the twentieth century, photographs taken by Native Americans were rarely written of or canonised, either due to a lack of interest on the part of dominant cultural institutions; an understandable protectiveness of images of their own people on the part of the photographers, or a denial of accreditation for those Native photographers who worked as collaborators with and field assistants to authorised photographers.
} 
been "taken not only to record 'vanishing' indigenous cultures, but also to grease the wheels of assimilation" (Lippard 1992:15). The notion of Native Americans as 'out of time' and as historical anomalies has been the dominant visual discourse regarding both the taking and reading of photographs of them.

Several key works helped solidify these readings in both academic texts and popular American culture. Firstly, the photographs of "'vanishing' indigenous cultures" Lippard refers to often expressly reflected the policies of Manifest Destiny, in that they euphemised the genocide and forced assimilation of Native Americans as a 'disappearance' which was an unfortunate but unavoidable corollary of European progress (Pruecel 1998:18). Photographers who worked in a style which reflected these policies include Charles Bell, Frank A. Rinehart and Nicholas Choate. One particularly prominent example of this style was Edward Curtis' twentyvolume ethnographic photographic collection The North American Indian, published between 1907 and 1930. This work has had a lasting influence on what 'traditional' Native American life was thought to have looked like. The photographs include portraits of subjects (from numerous tribes from all over the continent) in ceremonial dress; depictions of religious observances; and scenes from everyday reservation life. A widely acknowledged feature of Curtis's project was the extent to which these images were staged for the camera's benefit, in often culturally insensitive ways: Curtis carried costumes he asked subjects to wear with little attention to the costume's tribal specificity, and he removed signs of modernity from the camera's line of vision (Lippard 1992:25). Curtis scholar Mick Gidley states that the photos in The North American Indian are "reconstructions, or, more accurately, constructions produced at the behest of a prevailing ideology" (Gidley, cited in Zamir 2007:615). Zamir points out that in highlighting the ideological positioning of Curtis's project, scholars such as Gidley cast Native Americans in a victimised role, denying them any agency in choosing or agreeing to how they were depicted. This 
is an issue which requires careful consideration when reading photographs of indigenous people taken by colonisers.

Studio portrait photographs from the late nineteenth and early twentieth centuries of Native Americans in (pseudo-) traditional dress or cowboy outfits, often depicting performers in medicine shows or acts like Buffalo Bill Cody's Wild West Show, have also had an influence on the way images of Native Americans are read by mainstream American culture. These photographs utilise a different style of romanticism to that of Manifest Destiny photography, one which Dickinson, Ott and Aoki refer to as a "carnivalized violence" (2005:102). The representation of Native Americans here is one of the noble savage, with subjects posed in aggressive stances, often holding props, before painted backdrops. The overall effect is close to the 'cowboys and Indians' genre, where "the colonization of the American Indian becomes a hyper-dramatic play - a performance that simultaneously enacts and denies the racialized oppressions inherent to the story of the West" (Dickinson et al 2005:104). It should be noted that this interpretation is not the sole way of reading these images, though it does constitute a large part of how they are read by dominant culture.

While the purported Crazy Horse photo predates these types of portraiture, their influence means that modern readings of the photo draw on the discourses derived from them. As Faris indicates, photography of Native Americans is often

guided by a series of other discourses (as are all photographs). These are often discourses premised on the hierarchies of civilized/savage, sedentary/nomadic, modern/traditional, anthropological knowledge/local ideology, and West/Other (2003:88).

Despite the growing proliferation of politicised re-readings and writing regarding colonial photography on the part of contemporary Native writers, scholars and artists, these visual discourses still dominate many mainstream and popular cultural responses to photographs of Native 
Americans. Deloria writes that photography has been "a weapon in the final skirmishes of cultural warfare in which the natives of North America could be properly and finally embedded in their places in the cultural evolutionary incline" (Deloria, cited in Lippard 1992:20). The militaristic language utilised here reflects how this medium is very closely tied to, and implemented in, the symbolic and actual violence which Euro-American history has perpetrated on the first inhabitants of the continent.

The ways that Manifest Destiny photography and Wild West show photography influence how the purported Crazy Horse photograph is discussed and how viewers are disposed to read it will be considered in detail in chapter three. These influences exemplify how images are never read as isolated texts. Rather, interpretations of images are always guided by prior expectations of aesthetics, genre, cultural experience and display context.

\subsection{The Cultural Field of the Museum: Discourses and Contexts}

As the purported Crazy Horse photograph is owned by and exhibited in a museum, the contexts and concepts which inform this type of institution are relevant to how the claim about the photograph is produced and received. This cultural field and its discursive effects will be explored further in my third chapter. Leon and Rosenzweig make the point that how a museum displays information and objects affects the meaning that visitors draw, and that this form "cannot be separated from ... the complex social, cultural and historical contexts in which [the museum] is situated" (1989: xix). As a consequence of their close relation to the fields and institutions of the human sciences, museums have generally reproduced the scholarly and disinterested discourses and techniques of those fields; accordingly they have tended to avoid showing potentially upsetting, controversial or overtly politicised material. In the case of museums that cater to a general audience, this means that (to a certain extent) there is an avoidance of confronting that audience's preconceived notions of history (Nason 2000:40). 
Dickinson et al.'s work provides a useful analysis of how museums with an interest in Frontier and Native American history function as sites of memory and national identity. They make the point that many museums of this type also utilise discourses of "carnivalized violence" (2005:87) and of reverence (2006:27) in order to absolve visitors of any guilt associated with the horror of colonisation. In other words, violence in these institutions is represented in a manner that is playful, euphemised and distant, often articulated through an emphasis on battle minutiae or recreations-as-spectacle; or else it is approached with a reverence which on one hand encourages a "profound sense of respect", and on the other "a distanced, observational gaze" (2006:28). This kind of interpellation invites visitors "to respect and even celebrate Plains Indian culture and traditions" but without having to "consider the social and political implications of Western conquest" (2006:30-31). Dickinson et al. also emphasise that what a visitor learns in a museum is always influenced by their knowledge and experience of previous texts, and as such the majority of museums which focus on Native American history form "part of a dreamscape of the 400-year history of non-Native American representations of the continent's indigenous people" (2006:30).

Objects and texts displayed in museums help formulate stories about the past that, in a de Certeauvian sense, function less to tell us about the past than they do about the forms and categories through and by which subjects are interpellated. By way of example, Frontier and Western history museums often take on the task of addressing and answering the question of what it means to be American: the explanation that is commonly provided, with "its attendant values of individualism, democracy, selfdetermination and equality rests on the purposefully forgotten oppressions and rejections of the Other" (Dickinson et al. 2005:102). How the discourses of nationalism are utilised by the Custer Battlefield Museum impact upon the ways viewers are disposed to interpret and respond to the photograph claimed to be of Crazy Horse; this will be considered in detail in the third chapter. 


\subsection{Other Relevant Literature and Resources}

While the concepts and sources outlined thus far will inform my methodological approach, other sources will provide contextual, historical and theoretical material that is useful for this investigation. Firstly, this section will outline the sources I will analyse. Following this, the sources from the academic fields which have bearing on this investigation will be summarised.

My starting points in considering the claim that the photograph is of Crazy Horse are the newspaper articles and webpage through which the Custer Battlefield Museum articulates this claim. On the museum website, a page is devoted to the Crazy Horse exhibit ('Portrait of Chief Crazy Horse' 2009:n.p..). This page displays a reproduction of the photograph, and describes it in detail, noting technical features and other "noteworthy considerations", and refers to other texts which contain evidence supporting their claim. Two promotional newspaper articles, both published in 2003, are the sources of further information regarding both the museum's claim and details of their purchase of the tintype. The first of these, "Proven' Sole 1877 Photo of Crazy Horse finds home at Custer Battlefield Museum' is written by Carl Rieckmann and was published in Big Horn County News, while James Hagengruber's 'Man Without a Face: Mystery continues in hunt for image of Chief Crazy Horse' is from the Billings Gazette. These articles both allow wide scope for the museum's representatives to state their case, though some discussion of arguments against the claim (voiced mainly by Lakota scholars and Crazy Horse's descendants) is offered. Notable, however, is the omission of any mention of the cultural politics inherent in this discussion. The way the webpage, and Rieckmann and Hagengruber's articles, frame and attest to the Custer Battlefield Museum's claim will be analysed in the second chapter, as part of the genealogical investigation of how the claim has been discursively developed and constituted in order to be naturalised as an (albeit fragile) historical truth. 
Further texts, referred to on the webpage and in Hagengruber and Rieckmann's articles, are drawn on as evidence for the claim: these include books, speech transcripts and oral histories that potentially point to who the photographer may have been, that offer descriptions of what Crazy Horse looked like which can then be compared with the image, and that are called on to establish the history of the photograph since it was taken and its line of title. The first of these is a pamphlet catalogue detailing the portfolio of frontier photographer James Hamilton, one image listed as 'Crazy Horse' (Hagengruber 2003:n.p..). In support of this, a transcript of a 1928 speech by Hamilton's son Charles (Hamilton 1972), who accompanied his father on a 1877 journey to take photographs at the Red Cloud and Spotted Tail Agencies, is also used to corroborate the museum's claim. Details of these texts will also be considered in the genealogy of the photograph.

Books in which the purported Crazy Horse photograph has been published and discussed are also cited by the museum, and these textual and discursive activities will also be analysed. The first of these is J.W. Vaughn's With Crook at the Rosebud (1994). First published in 1956, Vaughn's book provides an account of the 1876 Battle of the Rosebud, a conflict between the U.S. Army (and their Crow and Shoshoni allies) and the Lakota and Northern Cheyenne, which precipitated the Battle of the Little Bighorn eight days later. In one chapter, Vaughn discusses the Lakota contingent led by Crazy Horse, devotes several pages to accounts of what Crazy Horse looked like, statements regarding the lack of photographic representation of him, and "new evidence" which states that he was photographed, and that this image has been verified as a true likeness (Vaughn 1994:40-43). Similar claims are found in The Killing of Chief Crazy Horse (1988), by Robert A. Clark with commentary by Carroll Friswold, a text which the museum also refers to as evidence of their claim ('Portrait of Chief Crazy Horse' 2009:n.p..). Friswold, who owned the tintype at the time of the book's first publication in 1976, surmises as to the circumstances under which it was taken and why it remained hidden for so long, and provides a 
letter from a previous owner as provenance of the claim. These accounts, as well as those made by the museum, will be compared, and the discursive framing of their claims analysed.

As well as considering these texts, discussion of the rhetorical modes which have been utilised in writing about Crazy Horse will also be considered. As an historical figure he has been written of as a brilliant warrior and strategist, a tragic/romantic hero, a spiritual or quasi-religious figure, and as a powerful political icon in the indigenous struggle for autonomy. Richard Grimes' article, 'The Making of a Sioux Legend: the Historiography of Crazy Horse' (2000) provides a useful overview of how and where these different characterisations have been deployed. As well as this, historical details known about the life of Crazy Horse provide important context, as these necessarily inform his reception as an historical figure and as a significant figure in the resistance to colonisation. Some of the texts I will refer to include Black Elk Speaks (Neidhardt 2008), Crazy Horse (Sandoz 2008), The Day the World Ended at Little Bighorn (Marshall 2007), and the oral history provided by Crazy Horse's medicine man, Chips (Ricker 2005).

Other sources which respond to or contain material pertaining to the claims regarding the photograph are also of relevance: a 2004 article in the journal Whispering Wind by John Heriard entitled 'Debating Crazy Horse: is this the photo of the famous Oglala?' is one of the few sources which attempts to address and evaluate the historical evidence for and against the museum's claim, though the interest here is more in the historical and technological details which might sway the argument either way, rather than in the cultural politics of the claim itself. Regarding the museum's statements as to when and how the photograph was thought to have been taken, Ephiram Dickson III's 'Capturing the Lakota Spirit: Photographers at the Red Cloud and Spotted Tail Agencies' (2007) provides some useful context. Though Dickson's article does not refer to the photograph directly, it does give a detailed account of Hamilton's journey from lowa to Nebraska in 1877, and contextualises this within the ways commercial photography operated at the time. Dickson also discusses some of the 
cultural politics of late nineteenth century photography, accounting for why and how some Native American photographic subjects took advantage of this medium, while others resisted or were unwilling to be photographed.

Vine Deloria's extensive body of work on numerous issues affecting Indian country, both historically and contemporarily, will be used to situate the discussions of historiography and photography in relation to the Native American contexts which frame this study. In particular his book Red Earth, White Lies (1997) identifies the ethnocentrism of both scientific and historical doxa in North American and other western societies today. He shows how the supposed objectivism of these fields favours narratives, agendas and meanings which privilege dominant Euro-American forms of knowledge. These forms of knowledge are used by the museum to substantiate and authorise its claims, and so their use when discussing Native American history constitutes an important site of analysis. Deloria's other books, Custer Died for your Sins: an Indian Manifesto (1969) and Spirit and Reason (1999) will also assist in examining indigenous American history.

Partial Recall, (edited by Lucy Lippard, 1992), a collection of essays by indigenous American writers, contains some vital contextualising of both historical and contemporary readings of photographs of and by Native Americans. Similarly, the analyses of colonial photography in Photography's Other Histories (edited by Christopher Pinney and Nicholas Petersen, 2003) inform arguments of how photography, despite offering the theoretical promise of an eyewitness account, is often framed, discussed, and valued in terms of Western discursive regimes and logics: in this regard the essays in this volume by Hullah T. Tsinhnahjinnie and James Faris are of particular relevance. In the third chapter's discussion of Wild West Show photography, Linda Scarangella McNenly's Native Performers in Wild West Shows: From Buffalo Bill to Euro Disney (2012) will be used: McNenly discusses and analyses the history of these shows, how they are 
understood in contemporary culture, and how they were understood by the performers themselves.

There are texts which supplement my methodology in terms of theoretical approaches to photography and subjectivity. In addition to the methods outlined in Crary's Techniques of the Observer (1990), his book The Suspension of Perception (1999) provides a genealogical analysis of "attention since the nineteenth century ... and its role in the modernization of subjectivity" (1999:2). This allows for an extension of the methods used in Techniques of the Observer, specifically in terms of a consideration of how visual interpretation is informed by and extended through other forms of embodied experience.

Michael J. Shapiro's The Politics of Representation (1988) and John Berger's 'Understanding a Photograph' (1980) discuss photographs in terms of their status as discursive statements, and their relations to power and normative legitimacy. While Berger's essay is concerned with what the decision to photograph something says - and does not say - about the subject, Shapiro interrogates the power photographs have to confirm or challenge existing forms of authority. These arguments will not only inform how the Crazy Horse photograph itself performs as an image, but also assist in explaining how Crazy Horse's refusal to be photographed constitutes a political act.

The 'genre' of the Custer Battlefield Museum is an important factor in contextualising the ways that discursive statements about the photograph and the claims being made about it (in terms of its authenticity, cultural value and historical significance) are positioned. A Companion to Museum Studies (ed. Sharon Macdonald, 2006) provides a good general overview of the sub-disciplinary perspectives and contexts which inform how these institutions operate and display information; a chapter of particular relevance is Flora Edouwaye Kaplan's 'Making and Re-making National Identities', which discusses museums in terms of the ways in which they articulate and disseminate cultural ideas about the nation state. Similarly, Benedict Anderson's Imagined Communities (2006) articulates the 
relationships museums have to colonisation and hegemonic control, where the museum represents a site where "the colonial state imagined its dominion" (2006:168). These expressions of the functions of many museums illustrate some of the nuances of how the purported Crazy Horse photograph is presented in its institutional and cultural context.

Destination Culture: Tourism, Museums and Heritage (Barbara Kirshenblaat-Gimblett 1998) looks specifically at the way exhibitions narrativise the past for educational, entertainment and commercial purposes. Her descriptions of the various aims and functions of museums are especially relevant to the third chapter's discussion of how the Custer Battlefield Museum presents its information. Rosenzweig and Thelen's (1998) comprehensive investigation into how Americans understand and use history provides relevant data on the authority of the history museum; while Leon and Rosenzweig's collection of essays in History Museums in the United States: a Critical Assessment (1989) deals with sub-categories of the history museum, and the differing ways in which they interpret historical materials. These are not only useful to examining how the claim about the photograph is given legitimacy, but also to providing an understanding of how institutional styles, constraints and dispositions affect the ways it operates as a discursive statement.

The methodological tools and resources referred to here will be used to demonstrate the ways in which this photograph, and the claim that it is of Crazy Horse, are constituted as knowledge through various discursive operations. The techniques used in this work facilitate forms of symbolic violence where the text itself, as (supposedly) representative of a particular figure associated with a particular ethnohistory, becomes a body which can be narrativised, disciplined, subjected to violence, and appropriated.

\section{Conclusion}

Crazy Horse is an important figure in Indigenous American history, predominantly because he strongly resisted, literally and metaphorically, the narrative of the inevitability and desirability of the assimilation of 
indigenous Americans into dominant Euro-American societal frameworks. Accordingly, colonial histories have tended to transform Crazy Horse into a non-threatening and easily understood figure, while downplaying the radicalism of his resistance. From this perspective white audiences are free to admire him as a hero, without attending to or recognising the cultural and political circumstances which informed that resistance, and which inform their own cultural positioning now. The photograph purported to be of Crazy Horse plays a significant historical and discursive role, and as such its authenticity is attested to by a culturally valorised set of institutions, including the Custer Battlefield Museum. The photograph is identified by, and exhibited within, the museum in a manner that is commensurate with the modes of expression and notions of (historical, cultural, aesthetic) value dictated by the pedagogical, archival and commercial aims of such an institution. Within this context the photograph becomes a discourse of truth (arrived at and guaranteed by rigorous scholarly and historical methods) that scientifically and culturally reinforces colonial narratives of indigenous history. The next chapter's investigation of how this discourse of truth is constituted through texts and discursive statements illustrates the subtle ways that this reinforcement occurs. 


\section{Chapter Two: Genealogy}

\section{$\underline{\text { Introduction }}$}

The way in which a text and its history come to be constituted as knowledge is a complex process: it is made up of and characterised by a series of claims and statements, all of which, as Foucault attests, are subject to contestation (1980:34); and it usually ends with the valorisation of one among many competing positions and claims. Historical knowledge can often have a convoluted or erratic trajectory, moving from the speculative to become seen as the accepted and naturalised recording of truth. In this regard, the case of the purported Crazy Horse photograph involves not only the Custer Battlefield Museum's claim, but a history of other accounts, statements and texts which are cited as evidence that this tintype is an authentic representation of Crazy Horse. In looking at these texts, it is possible to see the traces of this claim, and how the museum's articulation of it is presented as a form of knowledge. I will demonstrate how these sources approach the claim that Crazy Horse was photographed, and how that information moves from being a popular but particularly powerful fiction, to a form of (historical) truth. This involves looking at the different ways that Crazy Horse has been represented, and the sources cited as supporting evidence by the museum and other related documents, as well as analysing and accounting for the photograph's discursive trajectory. In order to do this, I will describe some of the key forms that representations of Crazy Horse have taken. I will consider and evaluate the sources which the museum cites in support of their claim, the documents in which they make their claims, texts which rebut or respond to their argument, and the ways in which Crazy Horse and his reputed refusal to be photographed have been discursively positioned.

\subsection{Representations of Crazy Horse}

It is useful to consider the ways in which discussions of Crazy Horse as an historical figure have changed over the past century, as these differing perceptions and discursive styles colour and inform the approaches taken 
in discussing the possibility he was photographed. Richard S. Grimes traces Crazy Horse's elevation from "a skilled and respected warrior to the Lakota symbol of resistance to white domination and cultural assimilation" (Grimes 2000:278) in both popular and academic writing.

Initially, descriptions of Crazy Horse came from (mostly Euro-American) army members, who tended to concentrate either on his skills and bravery in warfare (as per Captain John Bourke's descriptions in his book On the Border with Crook (1891, rpt. 1971)), or on his perceived bloodthirsty and dangerous nature (as in the Sidney Telegraph obituary of Crazy Horse from 1877, cited in 'Alleged Photo of Ta'Shunke Witko', n.d.). These depictions of a leader whose accomplishments were primarily military in nature gave way, in the 1920s and 1930s, to descriptions of him as a more complex and multidimensional leader: "he was now viewed not only as a superior warrior and the leader of Sioux resistance to assimilation, but also as more accessible and human" (Grimes 2000:286). These descriptions were more likely to come from Lakota commentators and writers, such as Charles Eastman in his book Indian Heroes and Great Chieftains (1935, rpt. 2003); Luther Standing Bear's My People, the Sioux (1928, rpt. 2006); the Oglala oral histories from He Dog, Red Feather and Little Killer recorded by Eleanor Hinman and Mari Sandoz (Hinman 1976); and from Black Elk (Neidhardt 1932, rpt. 2008). However, although this particular style of description emerged in document form in the 1920s and 1930s, this does not mean that it did not have a prior existence. Historiographies such as Grimes' focus on the discourses authorised by dominant culture, which at this time meant written texts, and as such, the histories imparted by Black Elk, He Dog and other elders were not granted validity - and were in fact not known by Western academic and popular histories - until they were recorded and published.

From these oral histories a further discursive representation of Crazy Horse emerged, which incorporated the roles of great warrior and respected leader, but which also framed the chief as a tragic hero. This is strongly evident in Mari Sandoz's highly influential biography Crazy Horse: Strange 
Man of the Oglalas, first published in 1942: she describes Crazy Horse as being akin to "the ancient classical hero" (2008:48), a simile later to be utilised by Robert Clark in The Killing of Chief Crazy Horse (1976, rpt. 1988). The emergence of this style of narrative was accompanied by a turn to a romantic and 'fictionalised' style, "more literary than historical" (Grimes 2000:287). This led to accounts of Crazy Horse and his life being framed in messianic terms, as "a kind of Sioux Christ, betrayed in the end by his own disciples" (Hyde 1961:285). In contrast, other writers of the 1960s and 1970s, both Lakota and Euro-American, emphasised Crazy Horse's political resistance, drawing parallels with contemporaneous radical viewpoints and groups such as Red Power and the American Indian Movement. In Custer Died for Your Sins: An Indian Manifesto (1969), for example, Deloria writes that "Indians experienced an era similar to the Civil Rights Movement in the closing years to the last century [...] The Indian Struggle for freedom was symbolized by the great war chiefs Crazy Horse, Sitting Bull, Chief Joseph and Geronimo" (1969:198); while Peter Matthiessen's In the Spirit of Crazy Horse (1983, rpt. 1992) argues that "tribal traditionalists who embraced Red Power remained most closely aligned and identified with the symbolism of Crazy Horse as a Lakota hero" (Grimes 2000:292). These accounts acknowledged that Crazy Horse's defiance of and resistance to white authorities enhanced his legendary status, while simultaneously contributing to this process themselves.

From the 1980s onwards, there was a trend of describing Crazy Horse in a theoretically 'objective' style, where carefully referenced biographical detail was imbricated with contextualising information about Lakota and European society at the time. This tendency, exemplified by James Welch's Killing Custer (1994) and Evan Connell's Son of the Morning Star (1984, rpt. 2011), attempted to replace and go beyond the romantic and radical discourses which other writers had employed in discussing Crazy Horse. Another more recent approach is demonstrated in Joseph Marshall III's The Journey of Crazy Horse: a Lakota History (2004) and The Power of Four: Leadership Lessons of Crazy Horse (2009), which represented Crazy Horse 
as an exemplar of Lakota authority and virtue, from whom modern indigenous leaders might learn.

These depictions of Crazy Horse in oral and popular histories, as well as academic texts, have influenced how he has been perceived as an historical figure. In relation to the claims that a photograph of him exists, these modes of historical description have sometimes been employed in conjunction with each other: so, for instance, the representation of Crazy Horse as legendary or Christ-like might be juxtaposed with Crazy Horse the talented warrior and strategist, and then with the chief as human, both skilled and fallible; all of these sometimes within the same text. The argument that the Custer Battlefield Museum makes that their tintype is an authentic photograph of Crazy Horse draws on many of these discursive representations - although notably not the representation of him as a political radical.

The different ways that Crazy Horse has been represented and discussed, and the approaches taken in analysing purported photographs of him, can be better contextualised within a history, not only of events and people, but also of (written) representational styles. This history strongly affects the way in which the claims regarding a Crazy Horse photograph are framed and received. The following genealogy of the purported Crazy Horse photograph is presented against the backdrop of those modes of representation.

\subsection{Genealogy of the Photograph}

The earliest source which the museum refers to as evidence in support of their claim that the tintype they display is an authentic photograph of Crazy Horse is the catalogue pamphlet of the photographer James Hamilton, who took pictures of the Black Hills gold rush and of Native Americans at Agencies in South Dakota and northern Nebraska in 1877 (Hagengruber 2003:n.p..). The original copy of this pamphlet is owned by the Custer Battlefield Museum, and is relevant to their claim owing to its list of tintypes Hamilton offered for sale. Photograph 104 is listed as 'Crazy 
Horse': because of this, museum owner Chris Kortlander refers to it as the "smoking gun" in the evidence for a photograph of the chief (Hagengruber 2003:n.p..).

Hamilton's journey was recounted by his son and fellow traveller Charles in a 1928 speech to the Sioux City Academy of Science and Letters (published in Annals of lowa 1972). Though Charles Hamilton's speech discusses how his father travelled to the Red Cloud and Spotted Tail reservations to "obtain photographs of the fort, the agency, the noted officers of the army, the leading scouts and the leading chiefs of the different Indian tribes" (1972:826), it does not mention specifically that Crazy Horse was one of his subjects - although the mourning and activity at the Fort following Crazy Horse's death is described. This omission is intriguing, especially given Crazy Horse's fame at the time and after: a photograph of him would have been valuable politically, academically and economically then as now. Nevertheless, Charles Hamilton's speech and his father's pamphlet are items in a body of evidence that supposedly corroborates that Crazy Horse was photographed by James Hamilton, even though the links between the content of the documents and this claim are never made or shown to be explicit, and have to be inferred.

The use of Hamilton's account as both a form of provenance and 'eyewitness' evidence could potentially be compromised given that his speech was made in 1928 while reminiscing on a journey made 51 years before, when Hamilton was only fifteen years old. Taking this into consideration, it is interesting and perhaps significant that his statement about his father 'securing negatives of all the leading Indians of all the tribes at both Red Cloud and Spotted Tail Agencies" (1972:827) does not make reference to Crazy Horse posing for a photograph. Moreover, the details he relates of Crazy Horse's death do not appear to describe a man known (even casually, as a photographic subject) to the Hamiltons; in fact they would appear to corroborate the view that Crazy Horse distanced himself from white people, and was a source of anxiety and fear for the army and other invading frontiersmen. Hamilton writes that: 
There was an Indian chief named Crazy Horse who lived between Red Cloud and Spotted Tail Agency. He had quite a large following of Indians and they had started north on the warpath. The cavalry from Red Cloud Agency had pursued them, and they were arrested and brought back to Red Cloud. Crazy Horse was an ugly Indian and hard to handle. After they brought him back he conducted himself in a way so that it was necessary to place him in the guardhouse. While there he attacked a guard with a butcher knife, and the guard, in self defense, killed him by running a bayonet through his body. This killing created widespread alarm, and the Government officials were exceedingly nervous with reference to what might occur (Hamilton 1972:830-1).

This passage is also notable in that it relates the dominant, derogatory Euro-American perspective on Crazy Horse's death at the time, a viewpoint which subsequent writings about Crazy Horse have taken care to distance themselves from. Thus it is apparent how the claim of a Crazy Horse photograph is supported by 'factual' statements from testimonies like Hamilton's, such as the claim that "all the leading Indians" (1972:827) were photographed, while ignoring information from the same document as unfactual or overtly coloured by the prejudices of the time.

The first public appearance of the tintype where it was explicitly stated to be of Crazy Horse is in J. W. Vaughn's book With Crook at the Rosebud, first published in 1956 (rpt. 1994). Tracing the line of ownership of the image, as recounted by Friswold (in Clark, 1988) and Rieckmann (2003), the photograph was at the time owned by Fred Hackett. Vaughn's book makes claims about the circumstances under which the photograph was taken claims which differ substantially from later accounts by Friswold and the Custer Battlefield Museum. He states that the photograph was "dug up from [a] trunk" (Vaughn 1994:43), and that it was likely taken at Fort Laramie in 1870; in other words he places this seven years prior to the other accounts, at a point where Crazy Horse had only recently been made chief, and was unlikely to have spent time at white encampments. 
Vaughn cites Judge Eli Ricker's interviews, several letters from the National Archive, and correspondence with Mari Sandoz which give physical descriptions of Crazy Horse (Vaughn 1994:40-42), and then goes on to make reference to two other photographs that were claimed to be of him. Vaughn quotes from different authorities, such as members of the Oglala Tribal Council and Agency Superintendents, to debunk these claims. He then introduces the tintype owned by Hackett, and describes how Ellen Howard, daughter of the half-Lakota army scout Baptiste 'Little Bat' Garnier unearthed the tintype from amongst her late mother's possessions. Vaughn states that "Jake Herman, the Fifth Member of the Oglala Sioux Tribal Council, announced that he believed it to be the authentic picture of Chief Crazy Horse" (1994:43). Also published in the book is the text of a letter from Ellen Howard attesting to the authenticity of the tintype. Much as with the claims later made by the Custer Battlefield Museum, here previous historical belief is disproven and replaced by newer and supposedly more accurate knowledge. In Vaughn's book, the other photographs that are claimed to be of Crazy Horse are exposed as fakes, while the testimonies of Howard and Herman help raise this photograph to the status of an authentic and historically significant cultural text.

The next publication that deals with the tintype was The Killing of Chief Crazy Horse, first published in 1976; it includes posthumous commentary by Carroll Friswold, who had been the owner of the tintype until his death in 1969. Friswold makes confident statements regarding the line of ownership of the image: he contends that it was first owned by Little Bat, whose wife was a relative of Crazy Horse; after Little Bat's death in 1900 it went to his wife, and was then inherited by his daughter Ellen Howard; and from there, it was owned by Hackett, then Friswold. Friswold also describes the certificate of authenticity he received along with the tintype. This has evidently remained with the photograph as it has been passed on; the Custer Battlefield Museum displays a copy on their website. It is a typed letter signed by 'Mrs. Howard', stating that "many times did my father tell 
us in the family that this was truly a picture of Crazy Horse" ('Portrait of Chief Crazy Horse' 2009). It is worth noting that this letter of authenticity is significantly different from the text of the letter reproduced in Vaughn's book, which is slightly longer, is written in more broken English, and which grants Jake Herman of the Oglala Tribal Council "the rights to have [the photograph] published in a book or to whom ever he degnigated it to" [sic] (Vaughn, 1994:46).

Friswold details how Crazy Horse supposedly came to be photographed, writing that following his surrender at the Red Cloud Agency in 1877 "time was very heavy on his hands, the tiny details of everyday living were a nuisance to him, begging for supplies and food, or settling a quarrel between the women" (Clark, 1988:46). It was, according to Friswold's account, in this context that Little Bat persuaded Crazy Horse to come to Fort Robinson with him, and "with everyone in high good humour Bat dared Crazy Horse to have his picture taken, and he finally consented" (Clark, 1988:46). This detailed description of the events and their tenor is typical of much of the writing about Crazy Horse by Euro-Americans until the late twentieth century. Sandoz's biography employs a similarly detailed and conversational narrative tone, where the emotions and inner feelings of the individuals concerned are related in a manner which is consistent with fictional techniques (for instance, regarding the creation of a heroic, tragic or appealing 'character').

The Killing of Chief Crazy Horse attests to the contested status of this tintype, and to the difficulty of persuading all viewers, scholars and writers of the evidence that it is of Crazy Horse. In the preface to the 1988 edition of his book, Clark states his doubt that Friswold's commentary is accurate. Although Clark has "chosen not to dispute or alter [Friswold's] comments", he writes that he is unconvinced of the photograph's authenticity, arguing that "In view of the Oglala's short time at Red Cloud Agency, and his alleged aversion to the white man's shadow-catcher, it is unlikely that such a photograph exists" (Clark 1988:9). Clark's view, in opposition to Friswold's, is supported by the letters between Dr. Valentine McGillicuddy, 
the Fort Robinson doctor who administered to Crazy Horse as he was dying, and army interpreter William Garnett. This correspondence, published in Clark's book, was written in the 1920s and concerns the "historical events of the 1870s in which both men were involved" (Clark 1988:103). McGillicuddy is particularly emphatic in his letters to Garnett that Crazy Horse was never photographed, stating in a 1926 letter that "Crazy Horse never had a picture taken that I know of, and if there was one taken, someone sneaked up and took it, for he never would consent to being photographed" (Clark 1988:114). The two men also appear to have traded newspaper clippings of the different photographs claimed to be of Crazy Horse, with McGillicuddy writing of one in 1927 that "it certainly does not look like him as I remember him. I never knew of his having a photograph taken" (Clark 1988:128); and Garnett replying "I am very sure he never had a photograph taken" (Clark 1988:130). Taken along with Friswold's claim, it is evident that this expression of conflicting accounts within the same publication illustrates some of the difficulty any claim of an authentic photograph must negotiate.

The simultaneous recounting of (what is presented as) historical fact, and the use of romantic or quasi-literary language to describe events are also evident in Clark's book. The preface states, echoing Sandoz's descriptions (2008: 48), that the events leading up to Crazy Horse's death have "all the elements of a classical tragedy [...] and the final scene, the violent death of the warrior, is as stark and inevitable as though it were a play by one of the Greek masters of two thousand years ago" (Clark 1988:13). The effect of this is not only to provide the reader with an understanding of the emotive weight of the events, but it also depoliticises the impact of the power relations that shaped those events, in a way that forecloses both institutional and individual responsibility (Crazy Horse's violent death was 'inevitable'). What is more, these romantic discourses not only work to deny Crazy Horse status as a real flesh-and-blood subject, but also to deny the same to his tribespeople thereafter: in the preface to the 1988 edition, Clark writes that "What follows is the sad tale of a brave and proud man's 
death, a death that symbolized the unworthy end of a unique culture" (Clark 1988:10). This tendency to frame Crazy Horse's life (and especially his death) as merely a 'story' and to present Lakota culture as extinct are strongly imbricated forms of symbolic violence, and exist within the broader discursive phenomenon where Native Americans are presented as vanished or relegated to the past (Mihesuah 1996:77-8). The traces and reiterations of this tendency to discuss Crazy Horse utilising the techniques of fiction and to discuss indigeneity without reference to contemporary indigenous life remain to be seen in more recent texts and testimonies regarding the purported Crazy Horse photograph.

Between its appearance in Clark's book and its purchase at auction in 2000, the tintype appears not to have been published or promoted. According to Rieckmann's article, published after the Custer Battlefield Museum's purchase of the photograph, the amateur historian Pietro Abiuso "was instrumental in unearthing the original tintype and Howard letter in the effects of Friswold's estate" (Rieckmann 2003:n.p..); however it is not clear when this was. The tintype was purchased at Butterfield auctions in 2000 by an unnamed woman "who wanted to make sure [it] found a good museum home" (Rieckmann 2003:n.p..). Custer Battlefield Museum curator James 'Putt' Thompson then bought it, along with the Howard letter, on eBay for $\$ 6,500$. The statements of Charles Hamilton and Friswold are cited by the museum in the articles by Hagengruber (2003) and Rieckmann (2003) as being supportive of the tintype's authenticity. Friswold's story about Little Bat daring Crazy Horse to pose reappears in Rieckmann, for instance, with slightly different tonal emphasis: "It is presumed Little Bat persuaded the chief to have his picture taken with assurance that it would be kept secret while he was still alive" (Rieckmann 2003:n.p..). Here we see a shift from Friswold's account of high spirited dares to a portrait of a respectful and concerned Little Bat, mindful of potential exploitation; this, incidentally, also provides potential answers as to why the photograph never became public at an earlier date. 
Hagengruber and Rieckmann's 'popular press' newspaper articles are important sources, in that they include previous statements and claims about the photograph's provenance. In these articles, the Custer Battlefield Museum is able to outline their claim, the historical trajectory of the tintype, and some elements of the controversy around it. Both articles are also promotional, in that they report on the museum's recent acquisition of the photograph. They function as 'local interest' news, being published in the Billings Gazette and Big Horn County News respectively. This promotional aspect means that, while ostensibly providing a neutral and objective report about the museum purchasing the photograph, much of the evidence and research is provided by the museum itself. This means that even though the controversial aspects of their claim are conceded and dissenting arguments acknowledged, the historical material cited in detail is that which supports the museum's claim. Accordingly, when quoting from the Hagengruber and Rieckmann articles, I have occasionally written 'the museum states' or something similar; in this way I am identifying statements in the article which reflect the museum's position, or statements made by museum representatives such as curator Thompson or museum owner Chris Kortlander.

A notable adjunct to the museum's claim is their explanation regarding how a viewer is supposed to look at the photograph. Both the 'Custer Battlefield Museum' webpage (2013) and the Rieckmann and Hagengruber articles carefully explain that as a positive print, it is important to remember that a viewer will see a mirror image of the subject when looking at the tintype. It also provides a rationalisation regarding the scar Crazy Horse is reported to have had above his lip on the left side of his face: "A critic seeing no scar on the right side in the tintype would be forgetting it is not a modern photograph where subjects are flipped laterally as they go from negative to positive" (Rieckmann, 2003:n.p..). This seems disingenuous, since Rieckmann also claims that "for years naysayers have said they don't see a scar"; if this is the case, and only the "modern technological capabilities of high resolution scanning" (Rieckmann 
2003:n.p..) render it visible, then why would it matter which side of the subject's face casual viewers look for a scar on? Taken together, these citings of scientific and technological operations position the museum's claim as one that is authoritative: the explanations of how tintype photography works serve to make reading the photograph appear to be a specialised and technical process.

In presenting its claim as a form of truth the museum, in the Hagengruber and Rieckmann articles, does not simply articulate the position that, drawing on various documents and previous accounts, it has now been established that Crazy Horse was photographed and that this tintype is the sole photograph of him. Rather, there is an awareness that they are presenting an argument, and as such the measure of its success is going to be dependant upon how persuasive it is, rather than on how closely it represents the reality of historical events. For instance, Thompson states that "we believe, frankly, that we've proven it's Crazy Horse" (Rieckmann 2003:n.p..); while Kortlander states "my golden rule when purchasing something like this [is] can this piece be proven beyond a reasonable doubt?" (Hagengruber 2003:n.p..). This shows that what is at stake in the claim that this tintype is of Crazy Horse is not solely the truth or lack thereof of the claim, but also the ability to sway public opinion (while at the same time convincing academic and other institutional agents). The historical proofs that are cited are not meaningful because of their factual content; rather, they are meaningful because of their potential for influencing and changing what is accepted as being true or factual.

We can read the museum's 'persuasive' presentation of their claims as instances of the use of techniques of fiction in order to facilitate the "institution of the real" (de Certeau 1986:200). These techniques of fiction are commonly utilised in this type of heritage or 'popular' history, and various related fictive techniques are also evident in the museum's claim. These involve appeals being made to the imaginative, romantic, mythological, and contemplative, where we are asked to put ourselves into these discursive modes and to consider Crazy Horse in light of them. Thus, 
Hagengruber's article tells us that "an authentic photograph of Crazy Horse would be the Old West's version of the Holy Grail"; and "Although sasquatches are arguably the reigning kings of Western folklore, rumors of a Crazy Horse photograph can't be far behind" (2003:n.p..). Similarly, Rieckmann closes with an entreaty to "stare into the tintype's riveting, penetrating eyes, and make your own determination if it is Crazy Horse who has bridged more than a century to bring you the murderous chill you feel" (Rieckmann 2003:n.p..). These analogies and evocations serve to position Crazy Horse, and knowledge about him, as inherently speculative: this is in contrast to the 'scientific' accounting of historical proof. The effect of these conflicting discourses is to simultaneously position this knowledge as mysterious, vague and difficult to grasp, but also as being objectively provable and accessible to experts. Moreover, the reference to the Crazy Horse photograph in conjunction with mythological objects and animals also further serves to rob him of, or at least do violence to, his subjectivity and identity. It not only involves employing the techniques of fiction: it also fictionalises and objectifies Crazy Horse himself, specifically within a discursive regime that is politically and culturally antithetical to his practices and the positions he took.

The promotional tone of these articles is slightly more evident in Rieckmann's piece, which focuses on describing the man in the image in terms of the oral history from the medicine man Chips (recorded by Judge Eli Ricker in 1910, and published in Ricker 2005:273-6), and with regard to biographical details about Crazy Horse's life. Reference to people or arguments refuting the museum's claim are minimal, and are mainly offered as an introduction to the museum's counter-assertions; for instance, Mari Sandoz's claim that Crazy Horse was never photographed is framed as "an earlier historical presumption" (Rieckmann 2003 n.p..) which the museum's proofs overturn. Hagengruber's article, on the other hand, interviews historians and scholars (some of whom are Crazy Horse's descendants), such as Donovin Sprague and Don Red Thunder, who disagree with the museum's claims. Generally however the cultural politics 
inherent in the claim go unaddressed, as any acknowledgement of them would move the argument away from the process of the disinterested pursuit of knowledge and factuality.

The use Rieckmann makes of the oral history from the medicine man Chips is both selective and expedient. Abiuso corroborates the physical appearance of the man in the photograph with Chips' description of Crazy Horse (Rieckmann 2003:n.p.), but leaves out that Chips also states that “Crazy Horse never had his photo taken" (Chips, cited in Hardoff 1998:86). In this way, oral histories are appropriated for and deployed as evidence in order to support the claim, but are not given space to stand as legitimate histories on their own terms. This reflects how the Western academy "accepts non-Western traditions to the degree to which they help to bolster the existing and approved orthodox doctrines" (Deloria 1997:32). The selective inclusion and exclusion of particular forms of knowledge means that there is a simultaneous and imbricated marginalisation and authorisation of different subject positions at work in this historiography that is, the privileging of a Western/Euro-American subject.

Hagengruber's article was republished on the 'Friends of the Little Bighorn Battlefield' website ('Photo purported to be of Crazy Horse' 2008), together with several accompanying images, one of the tintype, and another of Abiuso and Thompson posing with a poster reproduction of it (posters like this are for sale in the museum store and on their website). Interestingly, this latter photograph does not allow an observer a particularly clear view of the poster itself. It would appear that this photograph has been taken not only to promote the work of the museum and its associates, but also to emphasise their ownership of the tintype. In other words, we are asked to regard the significance of the purported photograph of Crazy Horse not in terms of constituting and influencing historical knowledge, but as a valuable image to be possessed. The photograph of Thompson and Abiuso with the poster reproduction suggests or implies that, while it might be theirs to own and to proudly display, viewers might partake of this historical event and experience by 
purchasing the poster themselves. This very strongly reflects Crary's claim that the value of photography is not in its ability to represent the real, but rather that its value is due to its role as a "crucial component of a [...] cultural economy of value and exchange" (Crary 1990:13). Viewers are interpellated not only as subjects with an emotional, historical or cultural investment in Crazy Horse, but as potential customers looking to obtain valuable or desirable commodities.

The museum website, and particularly its webpage about the Crazy Horse photograph exhibit, is influential in establishing the status and authority of the claim that the photograph is of Crazy Horse. This is especially the case given that, for museum patrons or browsers of the webpage, the claim is presented as a largely unquestioned and authoritative fact: it is knowledge that may not have been accepted as or integrated into history in the earlier twentieth century, but is now convincingly established. There is little need, then, to cite expert opinion to lend the claim credence in this context, as here the museum constitutes that expert opinion. The webpage states, for example, that:

From eyewitness descriptions we know that Crazy Horse was five feet, eight inches tall, lithe and sinewy, with a lean face and a thin, sharp nose [...] There is a striking correlation between the eyewitness accounts and the man in the portrait ('Portrait of Chief Crazy Horse 2009:n.p..).

However, there is no reference as to authors of these eyewitness accounts. Similarly, the webpage opens with a header quote which is credited to Crazy Horse; however the source of where this is published or how it came to be known and recorded is not elaborated on. In this frame, then, the need for rigorous citation is clearly considered unnecessary, given that this is both a 'popular' history and a document deployed within an institutional (heritage museum) context; so in the former there is no need to employ academic citational practices, and in the latter the museum-as-authorised cultural site is not required to perform or establish its bona fides. 
The museum website frames the discussion of the photograph as a progressive accumulation and replacement of knowledge from the outset, stating that:

There was never a photograph taken or a likeness made from first hand witness of Crazy Horse', so said Mari Sandoz in the biography, Crazy Horse, the Strange Man of the Oglala. Her book was published in 1942. At the time there was little reason to doubt her words ('Portrait of Chief Crazy Horse' 2009:n.p..).

The implication here is that, rather than offering different possibilities or perspectives, the new knowledge offered by the museum replaces any former belief that Crazy Horse was never photographed, and that this former position was historically flawed and is now out of date. Hence, the claim is already positioning itself as powerful, legitimate, authoritative and enlightened in relation to the 'old' view that Crazy Horse refused to have his picture taken.

Not only is the argument that Crazy Horse was never photographed positioned as an anachronistic and inferior way of thinking, it is also positioned as politically suspect. The website proclaims that "Crazy Horse was not afraid of the 'shadow-catcher' as presumed by many writers" ('Portrait of Chief Crazy Horse' 2009:n.p..). This is reiterated in Rieckmann: "Thompson and others debunk the theory advanced by some writers that Crazy Horse was afraid of cameras" (2003:n.p.); and in Hagengruber: "Crazy Horse had no superstitious fear of cameras" (2003:n.p.). These repeated assertions of Crazy Horse's lack of fear and superstition imply that if one makes the claim that he was never photographed, one is thereby also saying that he was superstitious and afraid; that, in fact, these are the only reasons why he would have refused to have his picture taken. There is also the suggestion that those who claim that Crazy Horse was never photographed are employing a racial stereotype - that of the credulous Indian harbouring a fear that the camera would 'steal his soul'. This implication positions the museum's claim as being on the right and 
progressive side of cultural politics, establishing truth by "detaching it from the ideology of the past and revealing the past as ideological" (Althusser, cited in Foucault 1972:5).

Other sources more substantially explore the objections to the claim that this photograph is of Crazy Horse. Jack Heriard's article 'Debating Crazy Horse: is this the photo of the famous Oglala?' in Whispering Wind magazine, a long running journal on Native American heritage, crafts and material culture, provides an account of the arguments for and against the authenticity of the tintype, in order to "present both sides of this question from information [...] gathered through interviews and correspondence with individuals associated with the museum, Peter Abiuso, and others experienced in Plains material culture and the history of the frontier" (Heriard 2004:16). Nevertheless, it does not address the issues of cultural politics which surround the claim that the photograph is of Crazy Horse. Heriard's article covers much of the trajectory of the image that I have outlined in this chapter: he states that Friswold's evidence that the image was taken at Fort Robinson in 1877 is "only speculative" (Heriard 2004:18); and an image of the Howard letter of authenticity (the same one displayed on the museum webpage) is reproduced in the article (Heriard 2004:18). Following this, Heriard recounts further evidence provided by Abiuso in the form of oral history accounts of Crazy Horse's appearance, specifically the interviews with He Dog, Red Feather and Little Killer conducted by Eleanor Hinman in the 1930s (later published in Nebraska History in 1976 (Heriard 2004:23)). Abiuso also refers here to these accounts for descriptions of Crazy Horse's battle medicine, which he claims matches that held by the man in the tintype.

The language used in much of Heriard's article indicates that care has been taken to convey when a statement is opinion or speculation, and to credit viewpoints to those who state them, rather than necessarily presenting what his interviewees state as fact. For instance, he writes that "Abiuso feels that the man in the photo is holding an eagle bone whistle in his right hand"; "The photograph owners feel that this man appears to match the 
descriptions of Red Feather and Little Killer'; and "[researcher] Mike Crowdrey has observed that what appears to be a feather above [the subject's] right knee is not a 'central feather' as mentioned by He Dog, but is a left, outer tail feather" (Heriard 2004:18, emphases mine). This emphasises how, when looking at the tintype, much of what might be seen in it - even in terms of accurately identifying objects or describing appearances - is speculative and subjective.

Heriard goes on to discuss the photographer who may have taken the image, drawing on correspondence with photographic historian Ephiram Dickson (whose article about photographers at the Red Cloud and Spotted Tail Agencies in the 1870s is discussed below). The possibility that James Hamilton took the photograph (and gave it to Little Bat) is examined with reference to Charles Hamilton's 1928 speech, which describes a "little portable photograph studio my father had set up" (Hamilton 1976:830, cited in Heriard 2004:19). Heriard questions whether the painted backdrop, floor covering and studio chair visible in the photograph would have been possible for Hamilton to transport on his journey from Sioux City to Fort Robinson. Further doubt is cast given that the backdrop matches none of those in any of the pictures known to have been taken by Hamilton (Heriard 2004:20).

James Hamilton's pamphlet catalogue and the listing of image 104 as being of Crazy Horse are also discussed by Heriard. It is noted that Hamilton did not take all of the photographs he was offering for sale, and that this was not uncommon: "as competition for market share increased, so did piracy and availability of negatives when a photographer died or sold his holdings" (Heriard 2004:21). This competitive and tendentious business, where plagiarism and lack of attribution flourished, also led to instances where subjects might have been wrongly identified, either purposefully or by accident. As Heriard states: “image number 104, listed as 'Crazy Horse' in the Hamilton stereoscopic catalogue, is not conclusive evidence that Hamilton photographed Crazy Horse. It only implies that he was selling a photo which he claimed was of Crazy Horse" (Heriard 2004:21). 
In the final notes to his article, Heriard thanks "Putt Thompson of Custer Battlefield Museum, for allowing us the use of this photo and for introducing this author to this debate" (Heriard 2004:23). Alongside this is quarter page advertisement promoting the 'Limited Edition Crazy Horse Print' on sale at the Custer Battlefield Museum - the same posters as the one Abiuso and Thompson were photographed holding. The appearance of this advertisement, alongside Heriard's article which strives for impartiality, serves as a reminder that the museum is able to capitalise not just on the image itself, but also on the controversy and debate which surround it.

Though it doesn't mention the Crazy Horse photograph, Ephiram Dickson III's 'Capturing the Lakota Spirit: Photographers at the Red Cloud and Spotted Tail Agencies' (2007) contains information pertinent to the genealogy of the image. Dickson's article provides an account of the work that eight photographers undertook on separate visits to the Red Cloud and Spotted Tail Agencies in Nebraska between 1874 and 1877. One of these photographers was James Hamilton, the man whom the Custer Battlefield Museum claims took the photograph of Crazy Horse. Dickson details Hamilton's journey from Sioux City to Red Cloud Agency, from where he travelled to Spotted Tail agency in mid-August 1877; he stayed several weeks, photographing Army officers, chiefs and leading scouts. Dickson recounts how Hamilton and his son's plans to leave Spotted Tail in order to photograph the Black Hills gold rush were interrupted by Crazy Horse's death on September $5^{\text {th }}$ 1877. Dickson implies - though this is not made explicit - that Hamilton and his son were at Spotted Tail when Crazy Horse's body was brought there on September $8^{\text {th }}$.

Dickson draws on Charles Hamilton's speech in order to retrieve details about this journey, and he also mentions the eight-page catalogue of Hamilton's photographic works - presumably the pamphlet which the Custer Battlefield Museum now owns. Notable in Dickson's evaluation of Hamilton's accounts is the point that his work and his westward journey were strongly financially motivated. Dickson describes an environment of 
fierce commercial competition between Hamilton and other Sioux Citybased photographic studios, where the market for 'Indian views' was strong: moreover the more famous the subjects, the more commercially valuable they were. Given the intense national interest in Crazy Horse's surrender and death, it seems improbable that any photograph Hamilton took would not have been something he promoted extensively.

Dickson's article also describes Hamilton's photographic praxis when obtaining 'Indian views': this was first recounted in Charles Hamilton's 1928 speech, and is also described by Hagengruber. Many nineteenth century Native Americans posed willingly for photographs - chiefs such as Spotted Tail encouraged it, positing that images of the Lakota way of life could promote understanding and serve political interests (Dickson 21:2007). However, several of the photographers working in the area at this time describe practices of coercion and deception in taking photographs of unwilling subjects. Charles Hamilton states that:

The Indians had a superstition about having their pictures taken and would not consent unless some white man was beside them and had his picture taken at the same time. But my father very readily secured their pictures without their knowledge or consent (Hamilton, 1972:826-7).

This passage is also quoted by Hagengruber. Dickson's article also relates details of this practice, along with similar descriptions by other photographers, suggesting that this was not uncommon at the time. Given Hamilton's use of exploitative techniques, doubt might be cast as to whether he would have readily relinquished the tintype to Little Bat in order that the scout might keep the image secret until after Crazy Horse's death, as the Hagengruber and Rieckmann articles claim. Taken together with Hamilton's commercial dispositions and interests, and the fact that he offered a photo labelled 'Crazy Horse' for sale in his catalogue, the claim that Little Bat kept the photograph secret would appear to be contradicted by the documents the museum cites as supporting evidence. 
Dickson goes on to discuss some of the cultural politics at play in relation to colonial photography of Native Americans at this time:

the Lakota's discomfort with the camera perhaps had less to do with their supposed "primitive" fear of "shadow catching" and more about their growing distrust of how the images could later be used. Once the negative was made the subject no longer had control of the image. He could not specify which images were selected, how they were presented, or in what context [...]. Given the long history of Lakota-American relations they had good reasons to express concern (Dickson 2007:23).

This type of acknowledgement of the political power of photography is quite absent from the Euro-American 'popular history' texts which are cited in support of the purported Crazy Horse photograph.

Counter-arguments to the claim that this photograph is of Crazy Horse, largely from a Lakota perspective, have tended to characterise these claims as being unwelcome and invasive, particularly to his descendants and tribespeople. This is not to suggest that Lakota opinion on the provenance of a photograph is unanimous. Some Lakota historians, such as Joseph Marshall III (2004:281) and Don Red Thunder (as quoted in Hagengruber 2003:n.p.), state outright that Crazy Horse was never photographed; while others such as Donovin Sprague do not rule out that possibility entirely. According to Sprague:

There are a lot of people that want a photo of Crazy Horse, and I wouldn't go so far as to say that there isn't one that exists, but there are none that I've seen that are proven. He is on record that he did not want his picture [taken] (Sprague, in Higbee 2011).

Sprague also addresses the Custer Battlefield Museum's tintype directly, both in Hagengruber and in Higbee's documentary film, stating that "it's a nicely dressed man and he's posed in an elaborate studio - he [Crazy Horse] was never in an area like that; this has a tile floor and an elaborate studio 
backdrop" (Higbee 2011); and that "I'm sure [the Custer Battlefield Museum] has got some money in that tintype and they'd like to get that back, but it's never going to be Crazy Horse" (Hagengruber, 2003: n.p.). Sprague's statements effectively summarise several of the more prominent arguments regarding the purported Crazy Horse photograph, most particularly in terms of the material proofs that cast doubt over the claim (Crazy Horse was not likely to be found in a setting similar to the one depicted), and its contradiction of his stated refusal to be photographed.

Further questions arise from the claim that this photograph is of Crazy Horse. It might be asked if this is not a photograph of Crazy Horse, then who is the subject? There is suggestion that the photograph might be of fellow Little Bighorn veteran No Neck (Hagengruber 2003:n.p.), or of an actor who played Crazy Horse in a Buffalo Bill Cody-style re-enactment show (Heriard 2004:20). If the photograph is of No Neck, does he have descendants who may have a claim to or interest in ownership of the photograph? If it is of someone other than Crazy Horse, how might the tintype's cultural, historical or economic value be affected? These questions lead to other considerations and issues regarding the ownership, use and value of the photograph. If it is of Crazy Horse, as per the Custer Battlefield Museum's claim, then what, if any, rationale might be provided for it being owned and displayed by non-Lakota and outside Lakota territory? The museum website notes that the photograph is "available for public viewing" ('Portrait of Chief Crazy Horse' 2009 n.p.), which would suggest that knowledge about Crazy Horse is for the benefit of a general audience. This is a potentially controversial view given that it has been only within the last twenty years that Crazy Horse's descendants have publically identified themselves as such, in a "tradition of silence" which meant that many of those closest to Crazy Horse did not freely share knowledge about him, in accordance with his wishes (Newton 1995:1020). In light of the way in which knowledge about Crazy Horse has not (and is not) always treated as being 'for everyone' as part of his anti-assimilationist stance, the 
framing of it as knowledge for a general audience can be viewed as problematical.

\section{Conclusion}

The cultural and political issues considered thus far are based on and imbricated with a set of power relations that involve not only the exertion of dominant colonial power over a systematically disenfranchised colonised group, but which are also related to questions of knowledge, and who is granted authority to have and convey it. The genealogy of the purported Crazy Horse photograph illustrates the ways that the evidence for it being of him are influenced by these power relations, and by various discursive modes which position him as being a particular type of historical figure. The texts which relate to and address the photograph dispose viewers to a particular reading of Crazy Horse, his significance, and the cultural, historic, and economic value a photograph of him might have. However, it is not only this (written) genealogy which influences this reading: the photograph itself functions as a discursive statement. How this text functions as a visual discursive statement and the cultural fields which influence how this statement is read will be discussed in the following chapter. 


\section{Chapter 3: Visual Discourse and Related Cultural Fields}

\section{$\underline{\text { Introduction }}$}

The previous chapter discussed the purported Crazy Horse photograph in terms of its historical trajectory, provenance, and how it has been discussed: that is, the ways in which it has come to have meaning as a particular type of text. However, in looking at how the photograph and the claim that it is of Crazy Horse constitute a discursive statement which does a particular form of cultural work, it is also necessary to consider the role of the visual. There are ways in which viewers are disposed to read the image as a photograph, and this affects the perception of its epistemological, economic, historical and cultural significance. The photograph, and the written material accompanying it, comprise a text which makes a discursive statement. This chapter will elaborate how this photograph functions as a visual discursive statement, and the ways in which this statement, along with its written supporting material, is used to interpellate particular reading positions.

In doing this, it is also important to consider how this photograph, as a discursive statement, is influenced by the various cultural fields in which it is deployed, and that this position is in part responsible for the way in which we are disposed to read it. Two of these cultural fields are especially relevant and will be considered in further detail. Firstly, I will consider the field of photography, and how this has been used in creating popular images of Native Americans. These have fed into and been fed by dominant discourses, with a view to assimilating and in other ways marginalising this group. As such, this photograph can be read in terms of a particular configuration of political power, and can be seen as supporting and maintaining that power structure. Secondly, this photograph is exhibited in a popular history museum, and is therefore subject to the values, narratives and modes of address associated with this particular field. This type of museum, in that it conveys information about the history of a country, tends to promote a nationalistic and patriotic viewpoint, through (as I will argue), a discourse of unity which erases current inequalities and 
instances of othering. This discourse involves a politics which often tends to rely on disavowing or sanitising current and past forms of violence.

\section{$\underline{3.1 \text { Visual Discourse }}$}

The concept of visual discourse can be understood in relation to other forms of expression such as written, spoken, and behavioural discourses. If discourses "epitomise a particular configuration of power and knowledge, and act performatively to naturalize and universalize a particular worldview" (Mikula 2008:54), then visual discourse uses an image-based (as opposed to text-based, or social interaction-based) mode by which that performance is executed. It naturalises a worldview through how we are led to interpret and understand what we see as being a straightforward, obvious and taken-for-granted expression of truth.

These interpretations are not produced on their own, but are the result of mediation through other texts, forms of knowledge and doxic ideas and concepts: in other words, any visual discursive statement comes to be meaningful through our exposure to other texts and relationships, and through the discursive apparatus which accompanies, supports and displays the image. For instance, in the case of the tintype claimed to be of Crazy Horse, the image is presented (in the museum, on the museum website, and in the books and journals in which it has previously been published) with contextualising written text that explains its history, the claim that it is of Crazy Horse, and why this is thought to be so. This information orients and disposes us to towards certain positions and invites us to make particular interpretations based not only on this text, but also on the discourses and interpretations we already know of from related fields and similar representations. However, the justification for this written text is set up by the photograph itself, and the visual discourses which it presents and speaks to.

The purported Crazy Horse photograph must be considered in view of the discourses which govern photography as a medium and a cultural activity. Photography is discursive, in that the ways we are accustomed to talking 
about and writing about it are governed by particular modes of expression and sense-making. The relationship between photography and regimes of truth is both well established and complex. Michael Shapiro writes: "of all modes of representation, [photography] is the one most easily assimilated into discourses of knowledge and truth, for it is thought to be an unmediated simulacrum, a copy of what we consider the 'real'" (1988:124). The discourse of photography as reflective of truth is powerful and pervasive, and works to mystify and disguise the ways in which photography is able to "reproduce and reinforce the already-in-place ideological discourses vindicating entrenched systems of power and authority" (Shapiro 1988:126); alternatively, it can work to highlight and challenge these systems. Photography as a medium is thus able to be put to use to either reinforce or resist oppressive structures, but any 'truth' it represents is always politically motivated.

Just as history, as Bourdieu describes it, performs a form of "social magic" (1991:120) by legitimising its products through their relationships to authoritative structures, photography is able, through these legitimising fields, to reinforce its appearance as unmediated truth. In the case of the purported Crazy Horse photograph, this appearance is supported by the editorialising voice of the authoritative institution - that is, the museum. Viewers are guided as to how they should read the photograph through the provided descriptions: for instance, the museum website points out the blanket over the subject's arm, describes his earrings, and his "pose of peace", contrasting it with the poses of contemporaneous Native American photograph subjects, whom they claim often posed "wearing a fierce look and holding a favourite weapon" ('Portrait of Chief Crazy Horse, 2009, n.p..).

In this way, viewers are directed in their reading of the image: we are not simply invited to look at a photograph, nor even to look at one that is claimed to be of Crazy Horse: we are told what to observe as noteworthy, how to identify objects in the photograph that might otherwise be overlooked or unidentifiable, and steered towards a particular reading of 
expression, emotion and attitude. None of these elements of the photograph is inherently more notable than others: the earrings are not more obvious than his breastplate; and the stance referred to as the "pose of peace" is not notably unusual for photographs of the time. However, in drawing attention to them the museum firstly makes them appear significant, and secondly draws these points into the narrative of how viewers are to read both the image, and Crazy Horse as an historical figure. Further, these directions with regard to what to observe in the photograph serve to position the museum as authoritative, as an institution which holds and dispenses important knowledge and analysis, and which can be relied upon to provide the truth of the matter. As such, the museum's written information accompanying the photograph works symbiotically with the image itself: they justify and support each other.

Several of the elements of the photograph which the museum invites the viewer to attend to are not necessarily immediately obvious to the eye; in fact they cannot even be easily identified, owing to the age and resolution of the tintype. As noted by Heriard, the identifying evidence of the battle medicine, which supposedly matches that carried by Crazy Horse, is difficult to discern, and those objects "held in his right hand are unknown and an attempt to identify them would be speculative and not conclusive" (2004:18). Nevertheless the museum presumes a positive identification of them, claiming on its webpage that the man is holding "a peace pipe and its tamp with a clutch of Red Willow branches", and also noting that "The Lakota used the branch of the Red Willow (not tobacco) in the ceremonial smoke of a peace council” ('Portrait of Chief Crazy Horse' 2009:n.p..). Thus the image and the objects which supposedly appear here are meant to be examples of, and stand in for, traditional Lakota life and culture more generally, rather than focussing on Crazy Horse in particular. This both reinforces the museum's ability to provide expert analysis of the image, and also contextualises the results of that analysis within wider historical and ethnographic discourse. 
The 'imaginative' mode in which viewers are encouraged to read the photograph involves looking at the man in the picture for clues to his identity - specifically, markers of emotional dispositions and character traits - which once identified are then used to argue that the man in the photograph is Crazy Horse. The website's description of Crazy Horse as having "a countenance of quiet dignity, but morose, dogged, tenacious and melancholy", and their assertion that there is "a striking correlation" ('Portrait of Chief Crazy Horse' 2009: n.p..) between the reported appearance of Crazy Horse and the man in the tintype directs viewers towards a particular understanding of Crazy Horse's personality. Viewers are thus disposed towards identifying and reading these personality attributes in the expression of the subject; in other words, once they are primed to look for signs of 'tenacity' and 'doggedness', the facial features can easily be made to seem commensurate with such a reading.

The face of the man in the photograph has been referred to and interpreted not only on the website, but also in some of the other texts in which it has been promoted or published. In Vaughn's With Crook at the Rosebud (1994), the image has been cropped, showing only the man's face and body, with the background and surrounding furnishings omitted. Rieckmann's 2003 article also reproduces a cropped version of the tintype, showing a full length portrait but also omitting much of the setting in which the man stands. These omissions centre the discussion of evidence for or against the claim that the photograph is of Crazy Horse on the supposed similarities of the subject to extant eye-witness descriptions of Crazy Horse and his clothing; or, as in the case of Vaughn's book, they remove much of the consideration of the image itself from the discussion, focusing on the photograph's line of title and the validity of previous owners' claims about it. As a result, the photograph as a whole, and the information and evidence that might be gleaned from the studio setting, are by omission shown to be of less importance than subjective interpretations of the

\footnotetext{
${ }^{2}$ Though the museum website does not provide a citation here, this description is from Captain John Bourke's book On the Border with Crook (1971:415).
} 
subject's face, and the historical detail which has ensued from the image text.

The aforementioned 'imaginative' reading of the purported Crazy Horse photograph can be read as an instance of discourse at work. The framing of the Custer Battlefield as a place where "theories, legends and myths abound" (Rieckmann 2003:n.p..), and of Crazy Horse in terms of his "grandeur and mystique" (Hagengruber 2003:n.p..) places the photograph's audience in a position of contemplative, internalised and individuated thought. Here, attending to the photograph and considering whether one agrees with the hypothesis that it is indeed Crazy Horse involves a separation of subjects, who must "make [their] own determination" (Rieckmann 2003:n.p..) as to the validity of the museum's claim. Thus, the spectacular aspects of this text function as what Crary terms a "technology of separation" (1999:74) where, through their isolation in this 'imaginative' mode, observers of the photograph are primed to accept the allure of the photograph as having a particular historical and cultural truth, weight and relevance. As a supposedly authentic representation of a specific historical figure, the photograph provides a link to that figure which is strongly personalised: as such the practice of observing the photograph is influenced by some of the dynamics and differentials of power which govern person-to-person interaction. This discursive closeness of the observer to the photographic subject provides an active viewer with the power to interpret, categorise, evaluate and appropriate the person photographed.

One of the primary ways this discursive work is carried out on the textual body is through its exchangeability. The photograph's placement in this museum context means that it is something viewers pay to look at, and can purchase reproductions of; so while the ostensible value of the photograph lies in the claim that it is of Crazy Horse, in practice it is seen as valuable because it can be exchanged and possessed. This importance of ownership is reinforced by the attention paid to the previous owners of the tintype by the literature commenting on the image's history, and in the emphasis on 
the details of the museum's purchase of it. Here the text's importance as a representation of a human subject is subservient to its commodity status; an emphasis which serves to erase, or at least draw attention from, the autonomy, value and subjectivity of the man in the picture.

This commodification of the photograph alongside the museum's performance of reverence with regards to Crazy Horse's inalienable cultural status involves what Foucault would call a will to knowledge (Foucault 1977). The text's existence as a commodity is justified through its placement in a museum, an authoritative pedagogical institution, where knowledge about historical events and personages is always framed as both necessary and beneficial. In this way, any financial capital gained from the photograph is justified by the knowledge-as-capital it also generates. The desire to possess the image can then easily intersect and overlap with the reverent attitudes that popular history discussions of Crazy Horse tend to adopt. Historian Abiuso's statement that he "can't wait to touch [the tintype]" (Hagengruber 2003: n.p..) reflects these simultaneously deferent and proprietary attitudes.

The wills to knowledge, power and visibility are all closely imbricated. The desire the photograph answers to see, touch, and know about Crazy Horse is reminiscent of and analogous to colonial regimes and practices, especially given its positioning as being for the consumption of a generalised North American audience. The need to see Crazy Horse for oneself is not purely driven by historical curiosity, but is tied in to the power and control it allows with regard to the subject, which is here figured as a knowable body. As with many photographs of Native Americans, this one is deployed in a way in which "its use assumes ownership of the subject, which is seen as static, completely 'understandable'” (Durham 1992:56). Moreover, if "the management of subjects depend[s] above all on accumulation of knowledge about them" (Crary 1990:15), then the exhibition of the photograph, along with perusal of the accompanying written texts about its history and Crazy Horse's life, constitutes an accumulation and dissemination of knowledge for the 
continued purposes of management of the populations of which Crazy Horse is part - that is, the Lakota. While this is not an overt operation of power, the history of the exploitation of indigenous peoples by Western academic and knowledge institutions means that the photograph exists in a canon where this form of knowledge-gathering is always related to colonial power.

As a text, the supposed Crazy Horse photograph throws this relationship to power into sharp relief, considering that Crazy Horse was resistant to colonialism, and one expression of that resistance was to refuse to be photographed. The simultaneous reverential and proprietary attitudes previously mentioned come into play here also. Even though the independence and freedom with which Crazy Horse is discursively associated are admired and valorised by the museum's representatives (Abiuso is described as being "passionate about Crazy Horse" and refers to him as "the ultimate warrior" [Hagengruber 2003: n.p..]), the desire for knowledge of and about Crazy Horse is still strong enough to directly contravene and vitiate his own discursive and political practices. This is done by remaining silent about, or at the very least recontextualising, Crazy Horse's politically resistant stance. Numerous other prominent indigenous leaders of the time, including Sitting Bull (Hunkpapa Lakota), Chief Joseph (Wallowa Nez Perce) and Geronimo (Bedonkohe Apache), were photographed, and this does not diminish the significance of their resistances. The compromising and diminishing of Crazy Horse's anticolonial stance lies in making a claim which directly contradicts the way in which he is believed to have chosen to express that stance. In making the assertion that Crazy Horse was photographed, the museum propagates a different production of the real, one with resonating historiographic effects.

The way the photograph facilitates particular operations of power is not only dictated by how photography as a medium is able to supposedly produce the real. Other cultural fields and sub-fields support the ways in which this photographic discursive statement comes to have meaning and 
authority: these have historic and institutional precedents. The following section will take up and consider the generic styles with which the purported Crazy Horse photograph is associated, and discuss it in light of the history of photography of Native Americans.

\section{$\underline{3.2 \text { Visual Discourse, Generic Modes and Photography of Native Americans }}$}

Photography, as noted by Deloria (1982), Lippard (1992) Katakis (1998) and Chaudhary (2012) among others, has been used since its inception to promote, encourage and naturalise particular discursive positions in relation to both colonisation and indigeneity. In the case of the United States, the generic modes of portrait photography of Native Americans in the late nineteenth and early twentieth century tended to involve depicting their subjects in such a way that promulgated the idea that their cultures were dying, or that depicted them as violent, barbaric and primitive. These types of representation form part of the overall narrative of the American West, and still have influence over the ways dominant American culture depicts and responds to Native American cultures today though, it is important to note, these interpretations are far from definitive, and many other readings, while acknowledging the problems around the ways these images are often deployed, focus on the ways in which they reinforce and reflect Native agency and identity (see, for instance, Zamir (2007) and McNenly (2012)). Traces of the dominant discursive forms, however, can be seen in both the formal elements of the purported Crazy Horse photograph, and in the ways in which it is presented and discussed. This section will analyse the photograph's formal qualities in relation to examples of these generic styles.

One of the discursive justifications for the violence inflicted on indigenous American communities was the policy of Manifest Destiny. This can be characterised as the rationalisation that colonisation, the accrual of lands and resources, and genocide or forcible assimilation of Native Americans were authorised by the divine right of Europeans to spread across the continent, establishing and instilling both democratic and Christian values 
and ways of life. This widespread justification of indigenous disenfranchisement also had the narrational corollary that the eventual demise of Native Americans as a race was inevitable: as nineteenth century historian Francis Parkman wrote, "they were destined to melt and vanish before the advancing waves of Anglo-American power" (1991:347).

The role of photography in relation to Manifest Destiny could be understood as a form of romantic record keeping: it constituted a way that this tragic but supposedly unavoidable imminent extinction could be sanitised for the Euro-American public, and that portraits of supposedly vanishing cultures could be kept for posterity. Much of the way that Manifest Destiny photography depicts its subjects is as being close to or part of the natural world, as another feature of the (exploitable) landscape, or as the 'noble savage'. The pervasiveness of the association of natural and noble traits with Native Americans eventually has led to them being read as signs of authenticity, and that there is an expected way of performing authentic 'Indianness'; while the representation of the assimilation and 'domestication' of Native subjects helped reassure "a new nation of the superiority of its beliefs and culture" (Pruecel 1998:18). Prominent photographers in this style included Edward Curtis, Frank Rinehart and Charles Bell. Curtis' photographs often employed several of these characteristic features at once: one of his most famous works, 'The Vanishing Race' (Curtis 1904), depicts several Navajo on horseback, riding away from the camera. The misty landscape the people are disappearing into figures the subjects as 'close to nature', while the low angle, the subjects' postures and the grandeur of the scenery invite the reading of 'nobility'. The title of the photograph, meanwhile, makes the connection to Manifest Destiny explicit. The portrait photography of Curtis and Rinehart also makes use of these discursive positionings of their subjects. They are often full length portraits, with careful attention paid to the displaying of costume, medicines and weaponry: subjects often pose holding objects towards the camera or with them draped over their arms, the better to be seen (as in the photo 'Mrs. Sarah Whistler, Sac and Fox' (Rinehart 1898)). 
The implication here is that it is not only the faces of the people of these supposedly dying cultures that must be recorded, but also their artefacts. The poses of the subjects are often intended to convey romantic or noble associations: the people depicted stand erect, either looking straight at the camera or gazing into the distance with eyes raised (as in Curtis' 1910 photo of the Northern Cheyenne chief Two Moons).

Given the prominence and popularity of this style of photography in the late nineteenth and early twentieth centuries, its influence can be read in the purported Crazy Horse photograph; and given its lasting popularity and dominance in terms of the ways Native Americans are represented in visual culture, these discursive associations are still evident in the display and discussion which surrounds the photograph. Firstly, the photograph is representative of the full-length portraits displaying clothing and possessions, with the subject's medicine, blanket, breastplate and other clothing presented (though not entirely clearly, as noted by Heriard (2004:18)). These features are carefully described and expanded on by the Custer Battlefield Museum webpage, and their cultural significance referred to - for instance that the willow pipe he is thought to be holding has a ceremonial function, and is held in the left hand as for the Lakota this hand "holds spiritual values as it is closest to the heart" ('Portrait of Chief Crazy Horse' 2009:n.p..). This is consistent with the Manifest Destiny photography habit of drawing attention to belongings and clothing of significance for the purposes of posterity, though the museum does not overtly suggest this is to commemorate a dead or dying culture as those photographs did. Rather, these details are used to both reinforce the claim that this photograph is of Crazy Horse, and to dispose casual viewers without specific knowledge of Lakota custom to read the image as 'authentically Native American', through the references to visions, ceremonies and spiritual values. The use, in Reickmann, of Charles Hamilton's descriptions of his father's photographic practice reinforces this idea of authenticity: one piece of evidence of Hamilton's cited in support of the museum's claim is that the Native Americans James Hamilton 
photographed "were dressed as frontier Indians are supposed to be dressed" (Hamilton 1972:827, cited in Rieckmann 2003:n.p..).

The background and studio setting of the purported Crazy Horse photograph are also of relevance here - the painting of the orientalised columns and ferns which serves as backdrop reinforce the idea of nature and exoticism, though this is of a generalised nature. The studio setting, with the chair, fringed hanging and tiled floor are typical of portrait photography of the time. It could be argued that this form of formal sitting can be read as a demonstration of assimilation in itself; that the willingness of some Native Americans to pose was evidence of the persuasiveness of the European fashion for personal photographic portraits. Hagengruber's article finds it difficult to reconcile the lack of a photographic record of Crazy Horse, given the popularity of the medium (Hagengruber 2003:n.p..). In this way, the discursive proofs the photograph provides, of Native Americans as close to nature, as noble, as 'authentically Indian' are framed as a given: there must have been a photograph of Crazy Horse, and this must be it because it confirms existing expectations about what such a photograph should look like, and what Crazy Horse must have been like. Along with the influence of and discursive similarities to Manifest Destiny photography, the generic mode of portraits of Native American performers in medicine shows and popular entertainments, such as Pawnee Bill's Historic Wild West and Buffalo Bill Cody's Wild West show, also has an influence on readings of the purported Crazy Horse photograph. Though it differs from this style in some important aspects, the extent to which this form has influenced how images of and texts about Native Americans are read in popular culture means that this photograph bears traces of that influence. These popular shows were travelling exhibitions, and were at the height of their popularity in the late nineteenth and early twentieth centuries. They provided entertainment and information pertaining to a glorified and romanticised interpretation of the Western frontier: typical acts might include trick shooting and riding; horse shows; displays of artefacts; dances; storytelling; and dramatic re-enactments of 
Indigenous/White conflicts, either of a general nature (for instance stagecoach ambushes), or recreations of notable battles. Many of the Native American performers in these shows played themselves, reprising the roles they had undertaken in the actual events. Portrait photography of performers was a significant feature of the shows: these images were displayed as part of the exhibition, were used promotionally, and were available for purchase by audiences.

Buffalo Bill Cody's Wild West show was one of the most famous and longest running of the genre. Dickinson, et al. characterise the image of the West depicted in this show as one which provided "a master narrative of the frontier" that "seemed like an invitation into living history", but that was "highly selective, dramatized and romanticized" (2005:86). The mythologising discourse the show embodied and disseminated has been "replayed throughout the twentieth century ... in movies, novels and political discourse" (Dickinson et al 2005:93). Many of the associations popularly made with the Old West and with 'cowboys and Indians' stem from the rhetorical mode employed in this setting. The depiction of these conflicts involved what Dickinson et al refer to as "carnivalized violence" (2005:87); that is, violence for the purposes of entertainment. It is not meant to be taken seriously, and it glosses over or ignores actual historical violence and its consequences.

The photographs of Native American performers in these shows, much like the work of the Manifest Destiny photographers, tended to be posed portraits, full length, and often depicted subjects in traditional or ceremonial regalia. The main points of difference are in the context and function of the texts: these were commercial rather than ethnographic or historical works, and while they sometimes presented the discourse of the 'noble savage', they were also likely to depict Native performers in ways that "correspond[ed] with the popularized image of the 'savage' Native American warrior that the public expects to see at Wild West shows" (McNenly 2012:91). This notion of 'expectation' is noteworthy, as it reflects how, even as discursive statements about the Old West were being 
formulated, the audiences held preconceived ideas about Native subjects as exotic others.

In the purported Crazy Horse photograph, the discursive mode which speaks to and is informed by Wild West show photography is both shown, and offered as a comparison. For instance, on one hand this is a work that is deployed commercially as well as for educative purposes, as souvenir postcards and posters for commemoration of an interest in or visit to the Custer Battlefield Museum. As noted previously in this chapter, viewers are disposed to look at the tintype as part of romantic, heroic and dramatic narratives. Rieckmann builds on the tropes of conflict between Europeans and Native Americans, describing Crazy Horse as "one of George Armstrong Custer's worst and last nightmares", and referring to the man in the photograph as having a "quietly threatening" countenance, which gives observers a "murderous chill" (Rieckmann 2003:n.p.). Hence the audience is presented with a reading which assumes familiarity with the mythologising discourses of the Old West, one where Native Americans are figured as a dangerous other through a set of binary distinctions between us and them, culture and nature, civilised and uncivilised, familiar and mysterious.

On the other hand, this discourse is also countered to a certain extent, as the photograph is also discussed in terms of the ways it doesn't align with this narrative. The Custer Battlefield Museum states that:

photographs of Indians of the time show them in full battle dress, wearing a fierce look and holding a favourite weapon, a rifle, axe or knife. Not so in this picture, the subject is uniquely without a weapon of any sort and is holding a peace pipe... ('Portrait of Chief Crazy Horse' 2009: n.p..).

In this way, the photograph is acknowledged as fitting within a canon of late nineteenth century photography (and its attendant discourses), but it is also framed as being radically different. Qualifiers such as 'uniquely' dispose the audience to think of it as one-of-a-kind, as aesthetically 
exceptional as well as historically notable. The claim of the ubiquity of weaponry and 'ferocity' in photographs of Native Americans at this time is erroneous, but in making this claim the museum positions Crazy Horse as existing alongside a particular media representation, though not comfortably fitting within it. He is therefore positioned as an exceptional subject who is, in this instance, peaceful and hence non-threatening; unlike, it is implied, the majority of Native Americans.

In light of the discourses stemming from the genres of Manifest Destiny and Wild West show photography, the ways in which Crazy Horse, as an historical, political and culturally important figure can be read are disposed and inflected. Firstly, we are invited to regard him within a context of conquest: he is here depicted as a tragic figure. Secondly, we are asked to consider him in relation to a group which he is also distanced from, in that he is here framed as representative of Lakota culture, but also distinguished from the supposedly ubiquitous 'fierce' representations of other Native Americans. These multiple and sometimes contradictory positions mean that several different expectations regarding Native Americans are in play at once, and that together these contribute to an image of Crazy Horse as formidable but not oppositional to a potential (Euro-American) audience. This allows for visitors to uncritically take the position of 'Crazy Horse aficionados' without a challenge to an admiration they may have for the museum's namesake Custer, to their own sense of the supposedly correct cultural politics with regards to Native Americans, or to an idealised, sanitised vision of the American frontier. The discursive frameworks of Manifest Destiny and Wild West show photography were "central for constructing, and authenticating, a particular view of America and of Nativeness" (McNenly 2012:75), and as such operated as a familiar touchstone when conveying information about nation and indigeneity. The tintype which is claimed to be of Crazy Horse meets potential viewer expectations regarding representation, but no attempt is made here to challenge them by highlighting the politics inherent within this depiction. 
The photograph, and the written texts which accompany it, not only reflect the influence of the related photographic genres, but are also commensurate with the discourses of its institutional context - that of the popular heritage or history museum. The following section will discuss how the discursive statements articulated through the photograph are expressed through and in relation to this particular cultural field, its values, and its associated discourses.

\section{$\underline{3.3 \text { The Museum as Cultural Field }}$}

The Custer Battlefield Museum is a small, privately owned institution that, in the Crazy Horse exhibit and in its displays more generally, commemorates and informs visitors about the Battle of the Little Bighorn, its major players, and the history of the North Western frontier. This type of institution is also instrumental in constituting and conveying expressions of nationalism to the general public. This section will elaborate on the functions of the popular history museum, its ties to nationalism, and the forms of violence expressed in their discourse.

The Custer Battlefield Museum incorporates features of a history museum, a living-history museum (in that it stages re-enactments), a local history museum (due to its proximity to the Little Bighorn Battlefield itself, and its involvement in the local communities), and a pioneer museum (in that it affirms connections to a particular episode of frontier history and heritage). The aims and functions of all of these institutions are to preserve and conserve artefacts and history, to educate the public about historical events and material culture, and to provide a commemorative or celebratory site through which to reflect on or revere objects, events, groups or ways of thinking. Barbara Kirshenblaat-Gimblett elaborates on some of these functions: of those she mentions, the Custer Battlefield Museum closely adheres to the categories of "a cultural centre for the keeping and transmission of patrimony"; "a school dedicated to the creation of an informed citizenry"; "an attraction in a tourist economy"; and "A memory palace, a stage for the enactment of other times and 
places, a space of transport, fantasy, dreams" (1998:138-9). Though it follows some of the tenets of 'New Museology', in that it aims to historically and culturally contextualise its displays and artefacts to a certain extent (Kirshenblaat-Gimblett 1998:138), the Custer Battlefield Museum remains faithful to more traditional models in the ways it articulates and insists upon its authoritative status, and interpellates its visitors or customers as recipients of information and emotive/imaginative stimuli, rather than as interlocutors in collaborative meaning-making.

One form of meaning-making which many museums engage in, including the Custer Battlefield Museum, is the creation, promotion and performance of a particular discursive understanding of national identity (Kaplan 2011:165). Museums are sites where representations and narratives of the history and formation of the nation-state can be displayed, both for the edification of outsiders (Kirshenblaat-Gimblett 1998:153) and as a self-reflection to citizens of that state. This presentation is not straightforward, especially where blatant contradictions exist in the narratives and accounts of national identity and nation-building. The negotiations modern museums must make in terms of representing nations formed through colonialism are especially fraught.

Benedict Anderson refers to the 'museumizing imagination' as part of the colonial project (2006:182). He is referring here to the taxonomic, archival and patrimonial characteristics of museums: they have traditionally been institutions which, via their status and authority, have been able to categorise and select what constitutes noteworthy history, and which parts of this are worth highlighting and conserving. The museum functions as one of the technologies of classification and surveillance that colonial powers utilise to maintain "a human landscape of perfect visibility" (Anderson 2006:189) for the purposes of establishing and maintaining socio-political control and hegemony. Through the site of the museum, the places, events, characters and meanings of the history of colonisation are made absorbable, easily understandable and, to a certain extent, neutral: they are of interest and value to the work of imagining and naturalising a 
nation-state, and importantly they work to occlude the forms of violence upon which that state is built. This is not always effected simply by omission; rather it is carried out by integrating sites, events, scenes and victims of violence into wider (and largely teleological) narratives of progress and civilisation.

The relationship of museums to Native American history and representation is contentious, especially as Native and Euro-American versions of and perspectives on historical events are often radically different (Rosenzweig and Thelen 1998:164-5). The negotiations involved in mediating the histories of conflicts, wars and interactions between Native and European Americans mean that the continuing impacts these have had on these groups and on the nation as a whole are generally not addressed directly; instead, they are presented as part of the past, without relevance to modern existence. The wars and conflicts of the past are presented either as "carnivalized violence" (Dickinson et al 2005:87) - as fun, entertaining and without real physical or structural consequence; or they are presented through a "rhetoric of reverence" (Dickinson et al 2006:28) where respect and appreciation for the past and for indigeneity are encouraged, but from a distanced, objective and impassive viewpoint which is simultaneously subject to the imaginative narrational imperatives of the spectacle. Through this reverential discourse, "the social guilt associated with the violent colonization of the West is assuaged" (Dickinson et al. 2006:29).

The ways the Custer Battlefield Museum articulates nationalistic and patriotic discourses are sometimes overt, sometimes subtle. Symbols and institutions strongly associated with nationalism are highlighted in the museum's promotional material: a Tomb of the Unknown Soldier is maintained on the museum grounds, and American flags are sold through the museum's website and gift shop (the flags can be flown over the Tomb to commemorate a date of the purchaser's choosing). The museum is also a destination which welcomes school groups and the armed forces: members of the National Guard and the U.S. Cavalry School visit to learn 
about battle formations and tactics, and about the Little Bighorn Battle as an important moment in U.S. military history.

There are also less overt ways in which nationalism is articulated within the institution. This is achieved in part by positioning the Battle of the Little Bighorn as a turning point in the history of the United States, an event from which a healing process began. In this frame, conflict between Euro- and Native Americans is an historical wrong, one which proceeding actions work to absolve and rectify: hence, the museum website details the 1926 'burial of the hatchet' ceremony at the Tomb of the Unknown Soldier, a symbolic gesture of reconciliation. It also provides information on the 2003 'Peace Through Unity' memorial at the nearby Little Bighorn Battlefield National Monument which commemorates the Native Americans killed in the battle. Though it is acknowledged that "their heroic sacrifices were never formally recognized until now", the impression given is that the monument therefore rights the (systematic, structural) lack of recognition that Native Americans continue to face: "this new Indian memorial brings all Americans full circle through the theme 'Peace Through Unity'" ("Peace Through Unity' Memorial Dedicated', 2013:n.p..).

The framing of colonial history as an error of the past, now corrected, is complemented by a discourse of the history of the frontier and the Battle of the Little Bighorn as being a matter of historical preference. The museum positions itself as occupying theoretically neutral ground: here, the pedagogical authoritative voice is forfeited for one which interpellates visitors to draw their own conclusions. The bronze busts of Sitting Bull and Custer which flank the museum entrance exemplify this presentation of two equal sides, as does the focus on both Native American and U.S. cavalry battlefield artefacts. Thus, visitors can satisfy existing predilections for history without having their preferences and interests challenged. As Nason writes, "what we learn from an exhibition is strongly conditioned by what we expect to see and what we think we already know" (2000:40). This issue of how museums interact with viewers' existing knowledge, and how beholden they are to reflecting or confronting visitor expectations is widely 
discussed within museum studies (see also Harrison 1997; Crane 2000:7; Falk et al 2011:327; and Leon and Rosenzweig 1989:xx). In the case of the Custer Battlefield Museum, there is an attempt made to satisfy several (often contradictory) visitor preconceptions of history and the museum experience.

The presentation of unity is, however, a fragile one: the museum is, after all, called the Custer Battlefield Museum. This name, emphasising the importance of one particular leader in the battle over the battle itself and its many players, stands in contrast to the nearby Little Bighorn Battlefield National Monument, formerly known as the Custer Battlefield Memorial. The name change of this site in 1991 was not without controversy, as it was seen as unnecessarily 'politically correct' pandering to 'revisionist' histories by its detractors (Dubin 1999:158). Two decades on, the remaining elevation of Custer over other participants and over the event as a whole as exemplified in the museum's name appears to adhere to a much more archaic mode of cultural representation.

The museum's presentation of a nationalistic perspective narrativises a particular historical event (the Battle of the Little Bighorn), and asks its audience to consider, in a reverent, interested but nonetheless dispassionate fashion, a battle between a divided American population which over the passage of time has reconciled and is now unified. Discontinuities are evident in this representation of nation, however, most obviously in that the reasons for both conflict and the ensuing theoretical unification are glossed over, and any reference to imperfections in the unity of nation, such as ongoing conflicts, oppressions or discrepancies in the distribution of power, is omitted. This is not to suggest that an overt focus on contemporary inequality is or should be the job of museums, but to highlight how this omission in the acknowledgement of symbolic violence results in the perpetuation of those same violences. This is done in a covert manner: symbolic violence "enables relations of domination to be established and maintained through strategies which are softened and disguised" (Thompson, quoted in Bourdieu 1991:24). Forms of symbolic 
violence, therefore, have impacts which are often not straightforward or easy to identify or articulate, as they are part of the way dominant groups maintain their position and make power relations appear natural and inevitable.

In this case, we can understand the Custer Battlefield Museum's selfarticulation as authoritative, and its ability to dispense knowledge and educate the public means that it is part of the dominant power structure: it is able to have its cultural production (both material and intellectual) recognised as legitimate. An institution in this position does not inherently exercise symbolic violence but, as discussed thus far in this chapter, the likelihood is increased when and where discourses of historical violence are drawn upon in order to utilise their familiar generic or narrational modes. If visitors to the museum have come to an understanding of the history of contact between Native Americans and Euro-Americans through the rhetorics of Manifest Destiny and carnivalised violence, then they are less likely to recognise the full subjectivity of Native Americans, and hence will perceive them as 'other'. The presence of an 'other' problematises the supposedly unified vision of present-day North America that the museum also promotes. It is this inclusionary discourse that simultaneously excludes which constitutes a form of symbolic violence.

The inclusionary discourse of national unity also allows for appropriations of marginalised groups to occur, in the way described by de Certeau (1988). The histories, stories and material culture of dominated groups are taken up and redeployed by dominant culture in order for that dominant culture to legitimise its own products and better understand itself. The 'we' that is implied by the discussion of nation is thus shown in this frame to be Euro-American: the history of Native Americans is used here to allow for a different perspective, but one that still foregrounds whiteness. This is particularly evident through the focus on the Little Bighorn Battle as being especially historically relevant: it is one example of many cultural sites where Native American lives are paid attention not in their own right, but in relation to Euro-American ones. 
If the context of the museological field in which the purported Crazy Horse photograph is exhibited emphasises a discourse where Native Americans are figured as 'other', then this has a strong impact on how viewers are interpellated to read the image. The viewer of the photograph is constructed as being potentially interested in Crazy Horse, while not having any specific knowledge about him (in contrast with the museum which, in this interaction, is represented as having that knowledge). In this sense, the Crazy Horse exhibit "invites visitors to listen to and gaze upon the other as an object of knowledge" (Dickinson et al 2006:35), the purpose of this knowledge being to understand more about themselves as (Euro)Americans.

\section{Conclusion}

The claim that the photograph exhibited by the Custer Battlefield Museum is of Crazy Horse performs three main kinds of cultural work, discussed in detail in this chapter. Firstly, the photograph's discursive status can best be understood as a visual statement that is derived from, and is an extension of, a specific discursive regime of power/knowledge. Secondly this discursive statement both has links with, and is then redeployed in, other cultural fields: of particular note, the genre of late nineteenth and early twentieth century photography of Native Americans. Thirdly, the popular history museum as a cultural field and organising context influences and is influenced by the photographic, social and cultural discourses associated with this image.

The purported Crazy Horse photograph comes to have meaning through its status as a visual discursive statement. This occurs via contextualising information which accompanies its promotion and exhibition: in captions and fora such as the Custer Battlefield Museum website, viewers' attention is directed to particular objects in the photograph and deflected from others; disposed to a way of seeing that appears universal, natural and automatic, but which is in fact historically and culturally specific, and which influences it towards particular understandings of and responses to power 
(Crary 1990:3). These issues are particularly relevant to the photograph's status as an object in a system of exchange: its value as a commodity, and as an image which can be bought, sold, reproduced and otherwise appropriated, supersedes its historical, cultural or intrinsic value. This operation of power involves a will to knowledge, where the deployment of the photograph as a form of knowledge is an inherent and unquestionable virtue. This constitutes a form of symbolic violence, in that it is in direct contradiction to the way Crazy Horse is reputed to have articulated his resistance to colonisation, through a refusal to be photographed (Trimble 2005). This is not just a denial of agency and subjectivity, but also works counter to the independence and freedom with which Crazy Horse is commonly discursively associated in both Native American and EuroAmerican historiographies.

Further symbolic violence is carried out through the use of generic modes associated with late nineteenth and early twentieth century photography of Native Americans: in particular, the purported Crazy Horse photograph shares formal aesthetics and contextualising information with photography which reflected the policies of Manifest Destiny. Through comparison with the work of Edward S. Curtis and Frank Rinehart, it is evident that the photograph contains similarities in pose, costume and emphasis, and is accompanied by similar discourses of historicity and authenticity. The other relevant (sub-)genre utilised here is that of performers in Wild West shows, which share commercial imperatives with the purported Crazy Horse photograph. Wild West Show photography is also used as a point of contrast, in order to distance Crazy Horse from the 'savage' stereotype, while still emphasising the validity and ubiquity of that stereotype. The association of this photograph with these generic forms means that the Custer Battlefield Museum is able to present the photograph through discourses with which it is assumed that visitors are familiar. As such, it offers an archaic and limited understanding of Native American identity. The institutional context in which the photograph appears - that is, the popular history museum - also utilises discourses which influence how 
viewers are disposed to read it. In particular, I have looked at the discourse of nationalism, and how this is affected by the Custer Battlefield Museum: this occurs both directly, in terms of its overt appeals to patriotism, and indirectly, through a rhetoric of national unity. The symbolic violence perpetuated through the exhibition and deployment of the Crazy Horse photograph is achieved through this emphasis on unity within a wider representation of Native Americans, (and Native American history, knowledge and epistemology) as other.

What this complex arrangement of discourse, knowledge, historiography and visual media works to do is to is to naturalise a particular way of seeing Native Americans, through the discourses surrounding the photograph claimed to be of Crazy Horse. This way of seeing situates Crazy Horse, and by extension and association, American indigeneity more broadly, as 'other' to mainstream American culture. This othering allows for the perpetuation of stereotypes of 'noble savagery' and of the positioning of Native Americans as objects of knowledge, rather than authoritative bearers of knowledge and active political agents. While the exhibition of the photograph appears well-intentioned, in that viewers are disposed to admire both Crazy Horse and Lakota culture, in fostering this admiration the museum has taken care to avoid any elements which may disturb or threaten this colonialist doxa. This means that references to or consideration of colonisation, cultural politics, and the details of Crazy Horse's resistance to assimilation are omitted. The display thus "absolves Euro-Americans of the violence of conquest" (Dickinson et al 2006:41). They can gaze on the history of an 'other' without the discomfort of acknowledging the racism on which this nationhood is founded and maintained, and from which they benefit. 


\section{Conclusion}

This research, in setting out to articulate and demonstrate how a photograph is deployed to establish certain forms of historical truth, has analysed how those truths are constituted through other texts: both ones that comment on the photograph directly, and ones with which it is discursively associated. These influence how viewers are disposed and interpellated to read the image, in terms of historical, cultural, and economic significance and value. I have also investigated how the cultural fields in which the photograph appears affect its meaning as a representation of an historical figure who stands in for particular events, politics, people and nations.

The history that the purported Crazy Horse photograph promulgates is not only one where he conceded to having his picture taken, but one that also accounts for the circumstances under which this supposedly happened, who took the photograph, and what has happened to it since. From this, a detailed, complex 'institution of the real' (de Certeau 1986:200) is created and authorised, one which naturalises and supports particular regimes of power. The operation of power/knowledge, in emphasising certain voices, texts and narratives and de-emphasising or foreclosing others, here involves creating a representation of Crazy Horse which is apolitical, and which also neutralises the lasting and damaging effects of colonisation. This constitutes a symbolic violence, in that it directly contravenes Crazy Horse's politically resistant actions and status.

A word length constraint has meant that it has not been possible to explore or address all the issues raised in this dissertation. Discussions of other photographs or images claimed as being of Crazy Horse might have offered useful points of comparison and contrast: for instance, are the claims regarding their authenticity and provenance constituted in similar ways to the Custer Battlefield Museum's tintype, and to what extent do they perform similar discursive work? Furthermore, as noted in chapter two, if this image is not of Crazy Horse then questions are raised as to who it 
might be: though investigations into the subject's identity are outside the scope of this research, they would nevertheless strongly affect the cultural and historiographic effect of the image. Considerations of the operations of power/knowledge with regard to other photographic subjects whose identity is debated, particularly those from colonised nations or groups, would also complement this research.

Analysing the visual and written discourses which go into creating this particular historiography illustrates the ways in which history does not simply describe real events, but creates meaning through its narratives of the past. Visual media such as photographs are utilised in this form of meaning making. As such, attending to the discursive and institutional processes that establish the purported Crazy Horse photograph as a form of knowledge is important to an understanding and critique of the imbrication of power and knowledge. 


\section{Bibliography}

'Alleged Photo of Ta'Shunke Witko'. First Nations: Issues of Consequence, dickshovel.com, n.d. Web. $6^{\text {th }}$ December 2013

Anderson, B. Imagined Communities. London and New York: Verso, 2006

Barthes, R. Camera Lucida. London: Vintage, 2000

Benjamin, W. Illuminations. New York: Schocken, 1968

Berger, J. 'Understanding a Photograph'. Classic Essays on Photography. A Trachenberg. (Ed) New Haven: Leete's Island Books, 1980. 291-294

Blair, C and N. Michel. 'The Rushmore Effect'. The Ethos of Rhetoric. M.J. Hyde

(Ed) Columbia: University of South Carolina, 2004. 156-196

Bourdieu, P. Language and Symbolic Power. J. Thompson (Ed). Cambridge, MA: Harvard University Press, 1991

--The Field of Cultural Production. J. Thompson (Ed). New York: Colombia University Press, 1993

Bourke, J. On the Border With Crook. Lincoln: University of Nebraska Press, 1971

Bray, K.M. Crazy Horse: A Lakota Life. Norman: University of Oklahoma Press, 2006

Buecker, T.R. Fort Robinson and the American West, 1874-1899. Norman: University of Oklahoma Press, 1999

de Certeau, M. --The Practice of Everyday Life. Berkeley and Los Angeles: University of California Press, 1984

--Heterologies. Minneapolis: University of Minnesota Press, 1986

--The Writing of History. New York: University of Colombia Press, 1988

Chaat Smith, P. 'Every Picture Tells a Story'. Partial Recall. L. Lippard (Ed). New Press: New York, 1992. 95-99 
Chaudhary, Z. Afterimage of Empire. Minneapolis: University of Minnesota Press, 2012

Churchill, W. Agents of Repression. Cambridge MA: South End Press, 1988

Clark, R. A. (Ed). The Killing of Chief Crazy Horse. Lincoln and London: University of Nebraska Press, 1988

Connell, E. Son of the Morning Star. New York: Farrar, Straus and Giroux, 2011

Crane, S. (Ed). Museums and Memory. Stanford: Stanford University Press, 2000

Crary, J. Techniques of the Observer. Cambridge Mass: MIT Press, 1990

--Suspensions of Perception. Cambridge Mass: MIT Press, 1999

Curtis, E. S. 'The Vanishing Race'. The North American Indian, portfolio 1, plate

1. Northwestern University Digital Library Collections. Photograph. 1904

--'Two Moons, Cheyenne Chief'. The North American Indian, portfolio 6, plate

213. Northwestern University Digital Library Collections. Photograph. 1910

Custer Battlefield Museum, custermuseum.org. 2013. Web. $6^{\text {th }}$ February 2013.

Deloria, V. Custer Died for Your Sins: an Indian Manifesto. New York: Macmillan, 1969

--Red Earth White Lies. Golden: Fulcrum, 1997

--Spirit and Reason: The Vine Deloria, Jr., Reader. B. Deloria, K. Foehner and S. Scinta (Eds). Golden, CA: Fulcrum, 1999

Dickinson, G, B. L. Ott and E. Aoki. 'Memory and Myth at the Buffalo Bill Museum'. Western Journal of Communication 69:2, 2005. 85-108

--'Spaces of Remembering and Forgetting: The Reverent Eye/I at the Plains Indian Museum'. Communication and Critical/Cultural Studies 3:1, 2006. 27-47

Dickson, E. 'Capturing the Lakota Spirit: Photographers at the Red Cloud and Spotted Tail Agencies'. Nebraska History 88.1, 2007. 2-25 
Dubin, S. Displays of Power. New York and London: New York University Press, 1999

Durham, J. 'Geronimo!'. Partial Recall. L. Lippard (Ed). New Press: New York, 1992. 55-58.

Eastman, C. Indian Heroes and Great Chieftains. Fairfield: $1^{\text {st }}$ World Library Literary Society, 2003

Falk, J, L. Dierking and Adams, M. 'Living in a Learning Society'. A Companion to Museum Studies. S. MacDonald (Ed). Chichester: Blackwell, 2011. 323-339

Faris, J. 'Navajo and Photography'. Photography's Other Histories. Eds: Pinney and Petersen. Durham: Duke University Press, 2003. 85-99

Fisher, J. 'Empire Makers: Earth Art and the Struggle for a Continent'. Public Art Dialogue 1.1, 2011. 119-136

Fixico, D.L. The American Indian Mind in a Linear World. London and New York: Routledge, 2003

Foucault, M. The Archaeology of Knowledge. New York: Pantheon, 1972

--Discipline and Punish London: Penguin, 1977

--Power/ Knowledge: Selected Interviews and other Writings. New York and Toronto: Random House, 1980

--The Foucault Reader. Ed. Paul Rabinow. New York: Pantheon, 1984

--Language, Counter-memory, Practice. Ithaca NY: Cornell University Press, 1986

--Madness and Civilization. Oxford: Routledge Classics, 2001

Frow, J. 'Michel de Certeau and the Practice of Representation'. Cultural Studies. 5:1, 1991. 52-60

Grimes, R. 'The Making of a Sioux Legend: The Historiography of Crazy Horse'. South Dakota History, 30.3, 2000. 227-302 
Hagengruber, J. 'Man Without a Face: Mystery Continues in Hunt for Image of Chief Crazy Horse'. Billings Gazette November $16^{\text {th }}, 2003$

Hamilton, C. 'Address of Judge Charles C. Hamilton before the Academy of Science and Letters of Sioux City, lowa, November 27, 1928'. Annals of lowa $41.3,1972.809-834$

Hardoff, R.G. The Death of Crazy Horse. University of Nebraska Press, 1988 Harrison, J. 'Museums and Touristic Expectations'. Annals of Tourism Research 24.1, 1997. 23-40

Heriard, J. 'Debating Crazy Horse: Is this the photo of the famous Oglala?'. Whispering Wind Magazine. 34:3, 2004. 16-23

Herrera, J. 'Not Even His Name'. Harvard Civil Rights - Civil Liberties Law Review 29. 1994

Higbee, P., dir. Tasunke Witco. TIE Media Services, 2011. Film.

Hinman, E.H. The Eleanor H. Hinman Interviews on the Life and Death of Crazy Horse. Garry Owen: Garry Owen Press, 1976

Hyde, G. Spotted Tail's Folk: A History of the Brule Sioux. Norman: University of Oklahoma, 1961

Kaplan, F.E.S. 'Making and Re-making National Identities'. A Companion to Museum Studies. S. MacDonald (Ed). Chichester: Blackwell, 2011. 252-269

Katakis, M. (Ed) Excavating Voices: Listening to Photographs of Native North Americans. Philadelphia: UPenn Museum of Archaeology, 1998

Kirshenblaat-Gimblett, B. Destination Culture: Tourism, Museums and Heritage. Berkeley and Los Angeles: University of California Press, 1998

Leon, W and R. Rosenzweig (Eds). History Museums in the United States: a Critical Assessment. Urbana and Chicago: University of Illinois Press, 1989 Lippard, L. (Ed) Partial Recall. New Press: New York, 1992 
Macdonald, S. (Ed) A Companion to Museum Studies. Chichester: Blackwell, 2011

Marshall III, J.M. The Journey of Crazy Horse: a Lakota History. New York: Viking, 2004

--The Day the World Ended at Little Big Horn. New York: Viking, 2007

--The Power of Four: Leadership Lessons of Crazy Horse. New York: Sterling Publishing, 2009

Matthiessen, P. In the Spirit of Crazy Horse. New York: Penguin, 1992

McNenly, L.S. Native Performers in Wild West Shows: From Buffalo Bill to Euro

Disney. Norman: University of Oklahoma Press, 2012

Mihesuah, D.A. American Indians: Stereotypes and Realities. Atlanta: Clarity Press, 1996

Mikula, M. Key Concepts in Cultural Studies. Houndmills: Palgrave Macmillan, 2008

Nason, J. D. "'Our” Indians: The Unidimensional Indian in the Disembodied Local Past'. The Changing Presentation of the American Indian: Museums and Native Cultures. Seattle and London: University of Washington Press, 2000. 2945

Neihardt, J. Black Elk Speaks. Albany: State University of New York Press, 2008 Newton, N.J. "Memory and Misrepresentation: Representing Crazy Horse". Connecticut Law Review 27. 1994-5. 1003-1054

Parkman, F. The Oregon Trail; The Conspiracy of the Pontiac Vol. 1. New York: Penguin Putnam, 1991

“Peace Through Unity' Memorial Dedicated'. Custer Battlefield Museum. custermuseum.org/indian_memorial.htm. 2013. Web. 17 ${ }^{\text {th }}$ November 2013. Pinney, C, \& N Petersen (Eds). Photography's Other Histories. Durham: Duke University Press, 2003 
'Photo Purported to be of Crazy Horse'. Friends of the Little Bighorn Battlefield. n.d. friendslittlebighorn.com/crazy-horse-photo.htm. Rpt. from Billings Gazette. 2003. Web. $5^{\text {th }}$ February 2013

'Portrait of Chief Crazy Horse'. Custer Battlefield Museum. custermuseum.org/crazy_horse_exhibit.htm. 2009. Web. 6th February 2013.

Pruecel, R.W. 'Learning from the Elders'. Excavating Voices: Listening to Photographs of Native Americans. M Katakis (Ed). Philadelphia: UPenn Museum of Archaeology, 1998. 17-26

Ricker, E.S. Voices of the American West: The Indian Interviews of Eli S. Ricker Vol. 1. R.E. Jensen (Ed). Lincoln: University of Nebraska Press, 2005

Rieckmann, C. "Proven' Sole 1877 Photo of Crazy Horse Finds Home at Custer Battlefield Museum'. Big Horn County News. June 19 ${ }^{\text {th }}, 2003$

Rinehart, F.A. 'Mrs. Sarah Whistler, Sac and Fox'. Boston: Boston Public Library. Photograph. 1989

Rosenzweig, R and D. Thelen. Popular Uses of History in American Life. New York and Chichester: Columbia University Press, 1998

Sandoz, M. Crazy Horse: Strange Man of the Oglalas. Lincoln: University of Nebraska Press, 2008

Schirato, T. 'My Space or Yours? De Certeau, Frow and the Meanings of Popular Culture' Cultural Studies (USA), 1993. 281-89

Schirato, T., G. Danaher and J. Webb. Understanding Foucault: a Critical Introduction. Sydney: Allen and Unwin, 2012

Shapiro, M.J. The Politics of Representation. Madison: University of Wisconsin Press, 1988

Standing Bear, L. My People, the Sioux. Lincoln: University of Nebraska Press, 2006 
Trachenberg, A. (Ed) Classic Essays on Photography. New Haven: Leete's Island Books, 1980

Trimble, C. 'What Did Crazy Horse Look Like?' IktomisWeb: A Lakota Journal, iktomisweb.com, 2005. Web. 20 ${ }^{\text {th }}$ November 2013.

Tsinhnahjinnie, H. T. 'When is a photograph worth a thousand words?' Photography's Other Histories. Eds: Pinney and Petersen, Durham: Duke University Press, 2003. 40-52

Vaughn, J. W. With Crook at the Rosebud. Mechanicsburg: Stackpole, 1994

Welch, J. with P. Stekler. Killing Custer. London and New York: Penguin, 1994 Yellow Bird, M. 'What we want to be called: Indigenous Peoples' Perspectives on Racial and Ethnic Identity Labels'. American Indian Quarterly, 23.2, 1999 Zamir, S. 'Native Agency and the Making of The North American Indian'. The American Indian Quarterly 31:4, 2007. 613-653 